\title{
El Niño-Southern Oscillation signal in a new East Antarctic ice core, Mount Brown South
}

\author{
Camilla K. Crockart ${ }^{1}$, Tessa R. Vance ${ }^{1}$, Alexander D. Fraser ${ }^{1}$, Nerilie J. Abram ${ }^{2}$, Alison S. Criscitiello ${ }^{3}$, \\ Mark A. J. Curran ${ }^{4,1}$, Vincent Favier ${ }^{5}$, Ailie J. E. Gallant ${ }^{6}$, Christoph Kittel $^{7}$, Helle A. Kjær ${ }^{8}$, \\ Andrew R. Klekociuk ${ }^{4,1}$, Lenneke M. Jong ${ }^{4,1}$, Andrew D. Moy ${ }^{4,1}$, Christopher T. Plummer ${ }^{1}$, Paul T. Vallelonga ${ }^{8, a}$, \\ Jonathan Wille ${ }^{5}$, and Lingwei Zhang ${ }^{1}$ \\ ${ }^{1}$ Australian Antarctic Program Partnership, Institute for Marine \& Antarctic Studies, \\ University of Tasmania, Hobart TAS 7004, Australia \\ ${ }^{2}$ Research School of Earth Sciences and ARC Centre of Excellence for Climate Extremes, \\ Australian National University, Canberra ACT 2601, Australia \\ ${ }^{3}$ Department of Earth and Atmospheric Sciences, University of Alberta, Edmonton T6G 2R3, Canada \\ ${ }^{4}$ Australian Antarctic Division, Channel Highway, Kingston TAS 7050, Australia \\ ${ }^{5}$ Institut des Géosciences de l'Environnement, Université Grenoble-Alpes, Grenoble 38400, France \\ ${ }^{6}$ School of Earth, Atmosphere and Environment, Monash University, Rainforest Walk, Clayton VIC 3800, Australia \\ ${ }^{7}$ Laboratory of Climatology, Department of Geography, Spheres, University of Liège, Liège 4000, Belgium \\ ${ }^{8}$ Physics of Ice, Climate and Earth, Niels Bohr Institute, University of Copenhagen, Copenhagen 2100, Denmark \\ ${ }^{a}$ now at: UWA Oceans Institute, University of Western Australia, Perth WA 6909, Australia
}

Correspondence: Camilla K. Crockart (camilla.crockart@utas.edu.au)

Received: 16 October 2020 - Discussion started: 10 November 2020

Revised: 31 May 2021 - Accepted: 13 July 2021 - Published: 9 September 2021

\begin{abstract}
Paleoclimate archives, such as high-resolution ice core records, provide a means to investigate past climate variability. Until recently, the Law Dome (Dome Summit South site) ice core record remained one of few millennial-length high-resolution coastal records in East Antarctica. A new ice core drilled in 2017/2018 at Mount Brown South, approximately $1000 \mathrm{~km}$ west of Law Dome, provides an additional high-resolution record that will likely span the last millennium in the Indian Ocean sector of East Antarctica. Here, we compare snow accumulation rates and sea salt concentrations in the upper portion $(\sim 20 \mathrm{~m})$ of three Mount Brown South ice cores and an updated Law Dome record over the period 1975-2016. Annual sea salt concentrations from the Mount Brown South site record preserve a stronger signal for the El Niño-Southern Oscillation (ENSO; austral winter and spring, $r=0.533, p<0.001$, Multivariate El Niño Index) compared to a previously defined Law Dome record of summer sea salt concentrations (November-February, $r=0.398$, $p=0.010$, Southern Oscillation Index). The Mount Brown South site record and Law Dome record preserve inverse
\end{abstract}

signals for the ENSO, possibly due to longitudinal variability in meridional transport in the southern Indian Ocean, although further analysis is needed to confirm this. We suggest that ENSO-related sea surface temperature anomalies in the equatorial Pacific drive atmospheric teleconnections in the southern mid-latitudes. These anomalies are associated with a weakening (strengthening) of regional westerly winds to the north of Mount Brown South that correspond to years of low (high) sea salt deposition at Mount Brown South during La Niña (El Niño) events. The extended Mount Brown South annual sea salt record (when complete) may offer a new proxy record for reconstructions of the ENSO over the recent millennium, along with improved understanding of regional atmospheric variability in the southern Indian Ocean, in addition to that derived from Law Dome. 


\section{Introduction}

Ice cores collected from the Antarctic ice sheet contain chemical signals that are used to reconstruct past climate conditions. Ice cores can be categorized as low-resolution (decadally to centennially resolved) and high-resolution (annually resolved) records. Low-resolution ice cores collected from low-accumulation zones of the Antarctic Plateau contain climate signals dating back hundreds of thousands of years. High-resolution ice cores contain more detailed climate signals over recent millennia. High-resolution ice cores are drilled in coastal regions in Antarctica, where snow accumulation is relatively high and basal complexity is minimal (Vance et al., 2016). Only a few regions in East Antarctica have sufficient annual snow accumulation rates and ice sheet depth to allow for millennial-length high-resolution ice cores (Vance et al., 2016). This is true for the Indian Ocean sector of coastal East Antarctica, where few millennial-length high-resolution ice cores have been collected from regions other than Law Dome (LD, 66.7697 $\mathrm{S}, 112.8069^{\circ} \mathrm{E}$; Morgan et al., 1997; van Ommen et al., 2004; Roberts et al., 2015). Multiple studies have highlighted the need for additional millennial-length high-resolution ice cores in the Indian Ocean sector of East Antarctica (Stenni et al., 2017; IPCC, 2013; Thomas et al., 2017; Vance et al., 2016). Such records are required to fill spatial gaps in reconstructions of Antarctic temperature variability, aid in calibrating radar estimates of net surface mass balance, and provide additional climate proxy records that enhance the confidence and reliability of global climate reconstructions. Additional ice cores may also contain signals for major sources of climate variability over the past millennia, including the dominant climate modes in the Southern Hemisphere: the Southern Annular Mode (SAM), the El Niño-Southern Oscillation (ENSO), and potentially the Indian Ocean Dipole (IOD). Understanding how these climate modes have varied in the past is important for a global initiative, the Past Global Changes $2 \mathrm{k}$ Network, that aims to integrate regional climate proxies to create global climate reconstructions over the past 2 millennia (PAGES 2k Consortium, 2013). Expanding the Past Global Changes $2 \mathrm{k}$ Network enables climate modellers to better understand natural climate variability, which in turn assists the reliability of future climate projections.

The dominant climate mode in the southern high latitudes is the SAM, characterized by synchronous atmospheric anomalies of opposing signs in the high latitudes and midlatitudes (Marshall, 2003). This entails low-pressure (highpressure) anomalies associated with a strengthening (weakening) of the circumpolar vortex and a contraction (expansion) of the westerly wind belt during positive (negative) SAM phases. The SAM, as an atmospheric phenomenon, lacks the persistence of coupled ocean-atmosphere climate modes and thus can change phase on weekly to seasonal timescales. A number of multi-centennial reconstructions of past SAM have been developed from tree ring and high- resolution ice core records (e.g. Abram et al., 2014; Dätwyler et al., 2017; Villalba et al., 2012; Zhang et al., 2010). Abram et al. (2014) developed a reconstruction of SAM variability (1000-2007 CE) using 25 proxy records, including an oxygen isotope record from the James Ross Island ice core. The lack of a SAM proxy in the high latitudes of the Indian Ocean means that these reconstructions may not represent the full circumpolar SAM state (Hessl et al., 2017). Goodwin et al. (2004) developed a proxy of wind strength in the south-western Pacific Ocean related to the SAM variability in sea salt deposition (in early austral winter) at LD. However, more recent work by Marshall et al. (2017) suggests that LD preserves only a weak signal of negative SAM in the snow accumulation rate. Vance et al. (2016) suggested that a new ice core collected from the MBS region may contain an independent SAM signal.

Although SAM is the dominant climate mode in the southern high latitudes, the ENSO also influences Antarctic climate. Globally, the ENSO is the primary interannual climate mode and is characterized by opposing sea surface temperature (SST) anomalies in the western and eastern equatorial Pacific (McPhaden et al., 2006; Dätwyler et al., 2019). Warm (cool) SST anomalies in the eastern equatorial Pacific are caused by the weakening (strengthening) of the easterly trade winds during El Niño (La Niña) events (Markgraf and Diaz, 2000; Trenberth, 1997). Despite its origins in the equatorial Pacific, the ENSO influences the southern extratropical and Antarctic climate via teleconnections (linked atmospheric anomalies in two geographically separate regions) generated by Rossby wave trains (Ding et al., 2011; Turner, 2004). Rossby wave trains result from reduced (enhanced) Walker cell convection in the tropics in austral winter during El Niño (La Niña) events. This causes the Pacific South American pattern of high-low-high (low-highlow) tropospheric pressure anomalies that propagate southeastward from the equatorial Pacific toward the South Pacific (Yiu and Maycock, 2019). Proxy records for the ENSO from tree ring, coral, and ice core records have been used to produce multi-centennial reconstructions of the ENSO (e.g. Braganza et al., 2009; Carré et al., 2014; Cobb et al., 2003, 2013; Dätwyler et al., 2019; Emile-Geay et al., 2015; Freund et al., 2019; Fowler et al., 2012; Grothe et al., 2019; Stahle et al., 1998). However, these reconstructions frequently disagree on past ENSO variability because both the individual proxies and the ENSO events that they respond to are geographically separate and distinct, and the magnitude and persistence of the ENSO teleconnections vary between events (Braganza et al., 2009). There are numerous signals for the ENSO from West Antarctic ice core records due to their location at the southern end of the Pacific South American pressure pattern (Turner et al., 2017). The Pacific South American pattern is associated with strong atmospheric anomalies (e.g. warming near the Antarctic Peninsula) during austral winter, and to a lesser extent spring (Ding et al., 2011). El Niño (La Niña) events are also known to weaken (strengthen) the Amundsen 
Sea Low, a quasi-stationary low-pressure region in the South Pacific, and have a significant influence on the West Antarctic climate (Hosking et al., 2013). However, several studies also suggest a complex and limited relationship with ENSO, at least for the surface mass balance and melt, as part of summer variability is inherited from the previous austral winter (e.g. Donat-Magnin et al., 2020). The ENSO also influences East Antarctica; for example, there is an ENSO signal preserved in the summer sea salt record from LD (Vance et al., 2013).

The IOD may also influence southern high-latitude climate, although the mechanism of this link is debated. The IOD is characterized by opposing SST anomalies in the western and eastern equatorial Indian Ocean and occurs at an interannual scale (Saji et al., 1999). Cool (warm) SST anomalies in the eastern Indian Ocean during the positive (negative) IOD phase are associated with enhanced (reduced) ocean upwelling offshore of Sumatra and Java. Enhanced (reduced) coastal upwelling is caused by strengthening (weakening) of the south-easterly trade winds. Positive IOD events result in increased Walker cell convection in the western tropical Indian Ocean and decreased convection over Indonesia, which acts to sustain the SST anomalies and surface wind patterns (Webster et al., 1999). IOD events begin in austral autumn, peak in spring, and decay with the onset of the Australian monsoon, which typically occurs in early December (Cai et al., 2013). Although the IOD predominantly influences the climate in regions near the Indian Ocean basin, Abram et al. (2020) suggest that IOD-related convection anomalies cause Rossby wave train patterns (similar to the Pacific South American pressure pattern in the Pacific) that extend across the Australian continent towards the South Pacific. This suggests that the IOD may influence the southern mid-latitudes, which may in turn affect Antarctic climate. Unlike the SAM and ENSO, it is unclear how the IOD interacts with the SAM in mid-latitudes, or whether the recent positive trend in the SAM enhances or suppresses any IOD link to high latitudes. Determining this will assist with understanding whether East Antarctic ice core signals could potentially be proxy reservoirs for the IOD or its resulting teleconnections, as reconstructions are currently limited to only one semi-continuous reconstruction over the recent millennium from coral records in the eastern equatorial Indian Ocean (Abram et al., 2020).

In this study, we present the first analysis of climate signals contained in the upper section of the new Mount Brown South ice core $(\mathrm{s})\left(\mathrm{MBS}, 69.111^{\circ} \mathrm{S}, 86.312^{\circ} \mathrm{E}\right)$ and an updated LD (Dome Summit South site, $66.461^{\circ} \mathrm{S}, 112.841^{\circ} \mathrm{E}$ ) ice core record. The MBS site was chosen according to a set of specific selection criteria by Vance et al. (2016): (1) 10002000-year-old ice at $300 \mathrm{~m}$ depth, but with sub-annual resolution using standard ice core analytical techniques (e.g. at least $0.20 \mathrm{~m} \mathrm{yr}^{-1}$ ice equivalent (IE) accumulation); (2) minimal surface reworking (estimated using a MODIS-based surface roughness estimate ground-truthed with laser altimetry flight line data); (3) minimal ice displacement or elevation change at $300 \mathrm{~m}$ depth using Lagrangian streamline tracing and published ice velocities; and (4) a significant teleconnection with the mid-latitudes distinct from the Law Dome region (for details of the above site-selection criteria, see Vance et al., 2016). The MBS record is intended to be complementary to the LD record by preserving signals for climate variability from the western sector of the southern Indian Ocean. Previous short firn ice cores (5-10 m depth) have been collected from the coast inland from the Mount Brown region (Vance et al., 2016). Previous studies using these short ice cores have focused on proxies for local temperature using oxygen isotopes (e.g. Smith et al., 2002), and regional sea ice extent using methanesulfonic acid (e.g. Foster et al., 2006). There are no studies using MBS ice cores to investigate potential signals for the ENSO, SAM, and IOD. The new MBS record presented here provides an opportunity to search for climate mode signals, which can later be integrated with established proxies to enhance and expand the confidence and reliability of past climate reconstructions and aid in understanding regional atmospheric circulation variability. The new MBS record is unique in that it contains multiple short ice cores that likely span the full satellite era, in addition to a long core, which is likely to span the past millennium. This coverage of the satellite era allows for a rigorous analysis of the variability of climate signals at the MBS site and dating uncertainties associated with surface reworking. Here, we carry out detailed analyses of the annual snow accumulation rates and sea salt concentrations in the upper section of three MBS ice cores to assess the hypotheses that the record contains signals for past climate variability at a highresolution that extend beyond short spatial scale variability (Hypothesis 1) and contains climate signals that differ from the LD record (Hypothesis 2).

\section{Methods}

\subsection{MBS and LD (Dome Summit South site) ice cores}

MBS (elevation $2084 \mathrm{~m}, 69.111^{\circ} \mathrm{S}, 86.312^{\circ} \mathrm{E}$ ) is a coastal wet-deposition (deposition via precipitation and scavenging by blown snow, Legrand and Mayewski, 1997) site located in Wilhelm II Land in the Indian Ocean sector of East Antarctica, approximately $1000 \mathrm{~km}$ west of LD and $380 \mathrm{~km}$ east of Davis station (see Fig. 1). Net surface mass balance estimates for the MBS region from airborne radar surveys suggest that the isochrone dating back 1000 years lies at approximately $300 \mathrm{~m}$ depth (Vance et al., 2016). Four ice cores were drilled at MBS in the summer of 2017/2018 within $100 \mathrm{~m}$ of one another (see Fig. 1). The drilling site included surface features of drifts and sastrugi that were up to $0.5 \mathrm{~m}$ high, running in a roughly easterly direction (see Figs. A1 and A2 in the Appendix for photographs and details). The cores drilled include one long core, MBS1718 (hereafter termed "Main", depth $295 \mathrm{~m}$ ), and three short cores, MBS1718Alpha, MBS1718-Charlie, MBS1718-Bravo (hereafter "Al- 
pha", "Bravo", and "Charlie", 20-25 m depth). The Main core was drilled from $4 \mathrm{~m}$ using the Hans Tausen drill (Johnsen et al., 2007; Sheldon et al., 2014), while the Alpha, Bravo, and Charlie ice cores were drilled from the surface using the Kovacs drill system, similar to the one used at Law Dome (Vance et al., 2015; Roberts et al., 2015). The cores were cut to $1 \mathrm{~m}$ "bag" lengths in the field and weighed to produce a $1 \mathrm{~m}$ resolution density profile for each core. No other core processing was conducted in the field. The Bravo core was collected exclusively for persistent organic pollutant analysis so it will not be considered hereafter, although high-resolution water stable isotope analyses from this core were considered for confirmatory purposes during dating the records presented here. The upper $0.5-0.8 \mathrm{~m}$ of the MBS ice cores were excluded in this study, as the year horizons for the top year (i.e. most recent year) are difficult to identify, and further analysis is required to refine this dating. Based on the findings of Vance et al. (2016), the MBS Main core likely spans the past millennium, and deeper ice core trace chemical and isotopic analyses are ongoing. However, precise dating for this study has only been undertaken on the upper section of the Main core $(\sim 20 \mathrm{~m})$ and two of the short cores (i.e. Alpha and Charlie cores). This period includes the satellite era, where satellite and reanalysis datasets are used to investigate the environmental conditions associated with climate signals preserved in the ice cores.

$\mathrm{LD}$ (elevation $1370 \mathrm{~m}, 66.461^{\circ} \mathrm{S}, 112.841^{\circ} \mathrm{E}$ ) is also a wet-deposition coastal site located on a small coastal ice cap in Wilkes Land in East Antarctica (see Fig. 1). The Dome Summit South core drilling location is $4.6 \mathrm{~km}$ south of the LD summit, has prevailing south-easterly winds and minimal katabatic influence, and preserves strong maritime signals (McMorrow et al., 2001; Plummer et al., 2012). Previous studies have reported snow accumulation of $0.680 \mathrm{~m} \mathrm{yr}^{-1} \mathrm{IE}$ (Roberts et al., 2015; van Ommen et al., 2004) and low mean wind speeds of $8.3 \mathrm{~m} \mathrm{~s}^{-1}$ (Morgan et al., 1997). The new LD ice core used in this study, DSS1617, was drilled in summer 2016/2017 and is intended to replace and extend the upper portion of the LD record presented in Vance et al. (2013), which used four successive short ice cores to cover the period 1990-2009. The new record presented here will extend to 2016, increasing overlap with the satellite era (and therefore calibration period) by 7 years (or 19\%) and reducing dating errors associated with combining multiple short ice core composites. Prior to 1990, the LD ice core record used in this study is the same as that used in Vance et al. (2013), DSS97. The DSS1617 and DSS97 ice core composites were combined using visual analysis of raw data of overlapping seasonal cycles in 1989/1990 using key dating analytes (see Sect. 2.3).

\subsection{Isotope and trace ion chemistry analyses}

Discrete samples for water stable isotope and trace chemistry samples were cut under trace clean conditions. In order to in- vestigate the optimal sample resolution over the satellite era for accurate dating, we cut $1.5 \mathrm{~cm}$ isotope samples in contrast to $3 \mathrm{~cm}$ chemistry samples over the upper portion of the ice cores $(\sim 20 \mathrm{~m})$. For detailed information on the trace clean discrete analysis technique, see Plummer et al. (2012) and references therein. The oxygen isotopes and ion chemistry in the MBS and LD ice cores were analysed according to established methods (Curran and Palmer, 2001; Curran et al., 2003; Palmer et al., 2001; Plummer et al., 2012). The VG Isogas SIRA mass spectrometer was used to determine the ratio of oxygen isotopes $\left(\delta^{18} \mathrm{O}\right)$ in the $\mathrm{LD}$ ice core, while the Picarro L2130-i isotopic water analyser was used to determine the water stable isotopes ratios $\left(\delta^{18} \mathrm{O}\right.$ and $\left.\delta \mathrm{D}\right)$ in the MBS ice cores. Isotopic values are expressed as per mil (\%o) relative to the Vienna Standard Mean Oceanic Water (VSMOW) standard. The Thermo-Fisher/Dionex ICS3000 ion chromatograph was used to determine the concentrations of trace ion chemistry (anions and cations), including sea salt concentrations (chloride, $\mathrm{Cl}^{-}$; sodium, $\mathrm{Na}^{+}$; magnesium, $\mathrm{Mg}^{2+}$ ), calcium $\left(\mathrm{Ca}^{2+}\right)$, and sulfate $\left(\mathrm{SO}_{4}^{2-}\right)$, as well as methanesulfonic acid (MSA). Non-sea-salt sulfate ( $\mathrm{nsSSO}_{4}^{2-}$ ) was calculated according to the methods in Plummer et al. (2012) and used in this study as a dating aid in addition to the usual suite of seasonal species mentioned above. Parallel sections of the MBS Main and Charlie cores were sent to the University of Copenhagen for impurity determination by continuous flow analysis (Bigler et al., 2011); however, we only consider the initial data available from the discrete analyses performed in Australia in this study.

\subsection{Ice core dating}

Annual depth layers were assigned to the MBS and LD ice cores using seasonally varying species, principally $\delta^{18} \mathrm{O}$, $n \mathrm{nsSO}_{4}^{2-}, \mathrm{Na}^{+}$, and the ratio of $\mathrm{SO}_{4}^{2-} / \mathrm{Cl}^{-}$, which has been shown to be an excellent summer marker in the LD ice cores (Plummer et al., 2012). Similar to van Ommen and Morgan (1996), the summer maxima in $\delta^{18} \mathrm{O}$ around 10 January are used. The climatology of hydrogen peroxide $\left(\mathrm{H}_{2} \mathrm{O}_{2}\right)$ is also used in selected sections for the MBS cores as confirmatory dating similar to that used for the LD cores (van Ommen and Morgan, 1996). Volcanic ash layers (indicated by $\mathrm{nssSO}_{4}^{2-}$ peaks) linked to the Pinatubo volcanic eruption in the Philippines in mid-1991 were used as a reference depth horizon to cross-check the annual depth layer chronology (Plummer et al., 2012; see Fig. 2). Each ice core was dated individually and independently, without reference to other site records to ensure independence of the method.

\subsection{Snow accumulation rates and sea salt concentration analyses}

The annual depth layers were used in combination with an empirical density model (in $\mathrm{kg} \mathrm{m}^{-3}$; see Eq. 1) to determine the annual ice equivalent snow accumulation rates (hereafter 


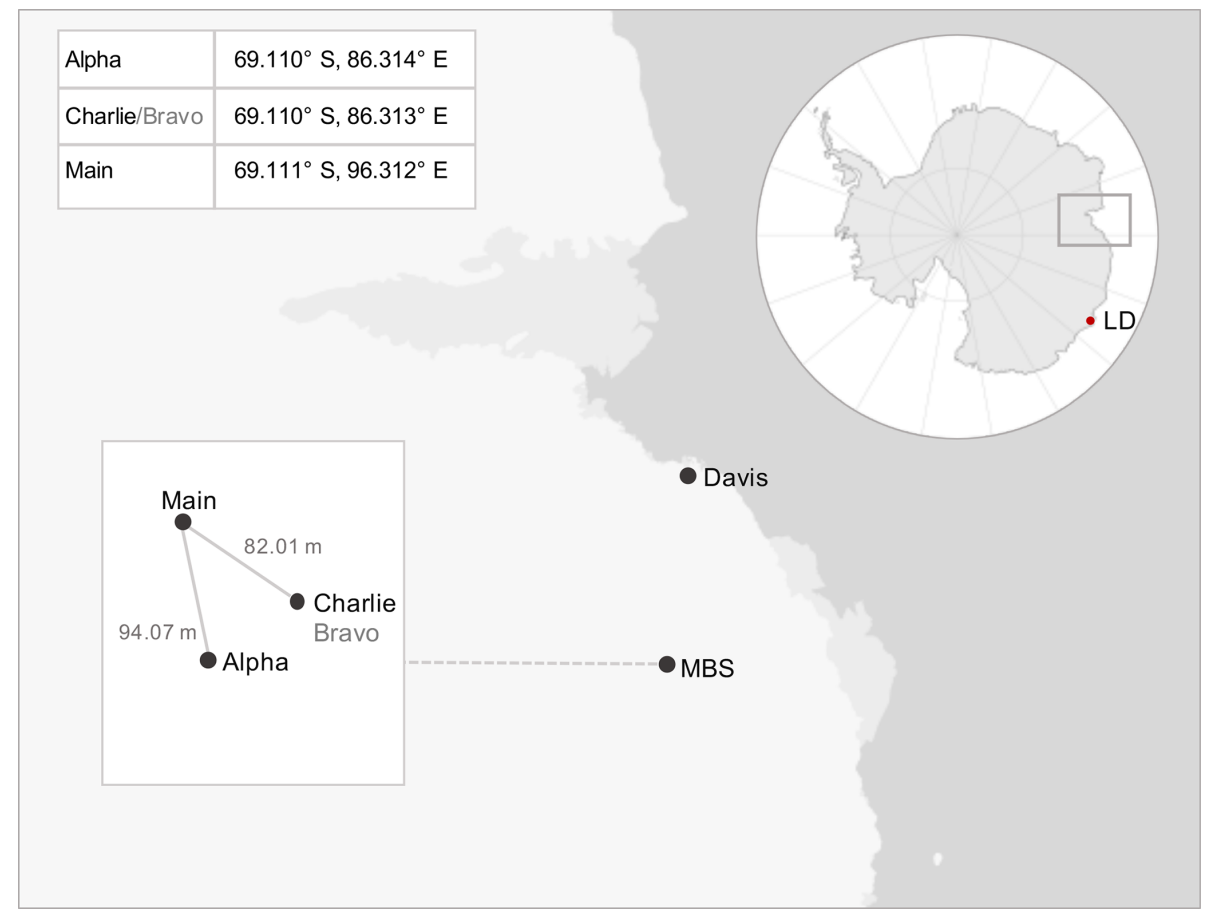

Figure 1. Site map of Mount Brown South (MBS) and Law Dome (LD, Dome Summit South site) in East Antarctica. The embedded table shows coordinates for the MBS Alpha, Bravo, Charlie, and Main ice core drilling sites.

accumulation) for the MBS ice cores. The empirical density model uses the mid-point depth of the annual layer $(d$ in $\mathrm{m})$ and the density of ice $\left(\rho=917 \mathrm{~kg} \mathrm{~m}^{-3}\right)$, corrects for variations in density in firn, and is based on the methods of Roberts et al. (2015).

$$
\begin{aligned}
\text { Empirical Density } & =[\rho]-[883.5356 \\
& \times \exp (-0.011078644 \times d)] \\
& +[436.8285]-[1.887488 \times d]
\end{aligned}
$$

Chloride was used as a proxy for sea salt in this study to maintain comparability with Vance et al. (2013), although sodium was also considered. We acknowledge that $\mathrm{Na}^{+}$is the more conservative proxy for sea salt (particularly in the Northern Hemisphere); however, we wished to compare like for like with LD in Vance et al. (2013). The trace chemistry analysis in the Australian Antarctic Program Partnership ice core laboratories is optimized to analyse anions in order to derive highly accurate methanesulfonic acid (MSA), $\mathrm{Cl}^{-}$, $\mathrm{SO}_{4}^{2-}$, and nitrate $\left(\mathrm{NO}_{3}\right)$ records, meaning that we tend to have fewer gaps in the $\mathrm{Cl}^{-}$record because of this anion priority. Moreover, based on the RACMO estimates of surface mass balance (Vance et al., 2016), MBS has sufficient accumulation (Benassai et al., 2005) to preserve the $\mathrm{Cl}^{-}$record, similar to LD.

Sea salt concentrations $\left(\mathrm{Cl}^{-}\right.$, hereafter sea salts) were log-transformed to create a normally distributed record, as the raw concentrations are skewed toward infrequent highconcentration events. The sea salts were then linearly inter- polated (i.e. binned) to monthly resolution to determine the climatology of the sea salts in the MBS and LD records. Annual rather than seasonal sea salts (and snow accumulation) in the MBS ice cores were used for all other analyses to avoid errors associated with linear interpolation that assume uniform accumulation throughout the year. The annual sea salts in the three MBS ice cores were averaged (hereafter named the site record) to minimize errors associated with dating uncertainties, such as timing noise (i.e. summer peaking analytes used as dating horizons depend on snowfall at the correct time to be preserved accurately, meaning that annual averages may include a small portion of signals into the adjacent year). McMorrow et al. (2001) suggest that snowfall events at LD have sufficient frequency to preserve monthly signals (i.e. linear interpolation errors are minimal). In addition, snow accumulation at LD is relatively uniform throughout the year, allowing seasonal LD records to be developed (Roberts et al., 2015). Previous studies have shown that seasonal LD sea salt records preserve signals for climate modes, such as the ENSO and the Interdecadal Pacific Oscillation (Vance et al., 2013, 2015); therefore, we consider the annual and summer (December-March) concentrations of sea salt from LD in this study.

To determine variability at the MBS site and between the MBS and LD sites, the accumulation and sea salts in the individual MBS ice cores and the LD record were compared using Pearson's correlation coefficient. The $p$ values for all analyses in this study are based on effective degrees of free- 

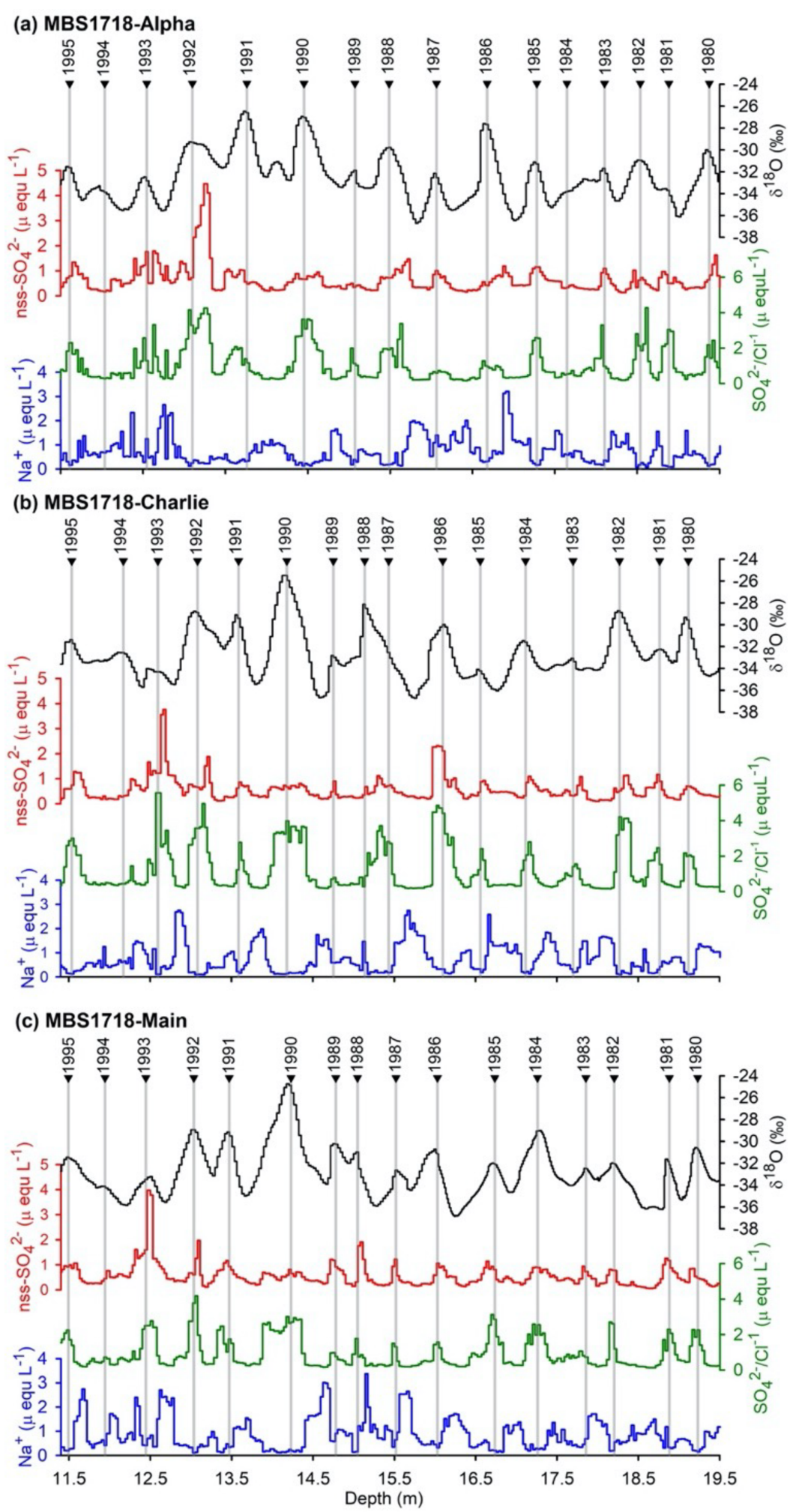

Figure 2. An $8 \mathrm{~m}$ long section from the Mount Brown South (a MBS1718-Alpha, b MBS1718-Charlie, and $\mathbf{c}$ MBS1718-Main) ice cores. These sections cover the period 1980-1995 (which contains some ambiguous annual horizons; see Sect. 3.1), with annual layers (year boundaries) shown as triangles with vertical grey lines. Annual horizons are identified from summer-peaking glaciochemical species, i.e. oxygen isotopes $\left(\delta^{18} \mathrm{O}\right)$, non-sea-salt sulfate $\left(\mathrm{nssSO}_{4}^{2-}\right)$ and the ratio between sulfate and chloride $\left(\mathrm{SO}_{4}^{2-} / \mathrm{Cl}^{-}\right)$. Winter-peaking sea salts $\left(\mathrm{Na}^{+}\right)$are used as a confirmatory species. Panels (a) and (b) are on the same depth scale as shown in (c). 
dom $\left(N_{\text {eff }}\right)$ calculated from a lag-1 autocorrelation, according to Bretherton et al. (1999). As the dating for the MBS record is still undergoing incremental improvement and may change in the future, analyses of the variability in accumulation and sea salts between the ice cores were repeated using a normalized Gaussian smooth (kernel $=3$ yearly points; $\sigma=0.6$ ) to minimize the influence of timing inaccuracies within approximately 1 year.

\subsection{Instrumental climate data}

To determine whether the MBS site record preserves signals of regional or hemispheric climate variability, the degree of correlation (lag-0) between the annual accumulation and sea salts against seasonal indices for the ENSO, SAM, and IOD was determined using Pearson's correlation coefficient. Seasonal indices, rather than annual, were used as these climate modes have their own temporal cycles that do not match the calendar year. For correlation against the annual MBS record, seasonal SAM indices were derived (i.e. DJF, MAM, JJA, SON), as the SAM exhibits high-frequency variability (weekly to seasonal). The ENSO indices were derived as average June-November SST anomalies, as convection anomalies related to the ENSO tend to emerge in early austral winter in the equatorial and south-west Pacific and propagate to higher southern latitudes during austral spring and into summer (Fogt and Bromwich, 2006; L'Heureux and Thompson, 2006). In addition, we wished to align as closely as practicable to the seasonal cycle of sea salt concentrations at MBS, which is likely highest during austral autumn to spring (similar to LD) due to decreased mid-latitude storminess in summer (Goodwin et al., 2004; see Fig. A3). We derived an austral spring IOD Index to align with the peak of IOD activity (Cai et al., 2013). As the summer LD sea salt record is known to preserve signals for climate modes (Vance et al., 2013, 2015), the summer record was correlated against seasonal climate indices as defined in Vance et al. (2013), in order to extend their analyses from 2009 to 2016 but remain comparable with this previous work. Note that we chose to use a standard spring for the ENSO SST indices (SeptemberNovember) rather than the September-October average used in Vance et al. (2013).

The ENSO indices used in this study include the Southern Oscillation Index (Parker, 1983; available from http://www.bom.gov.au/climate/current/soi2.shtml, last access: 3 September 2020), the Multivariate ENSO Index (Wolter and Timlin, 2011; available from https://psl.noaa.gov/enso/mei/, last access: 3 September 2020), and the Niño 3.4 and Niño 4 SST indices (Trenberth, 1997; available from https://climatedataguide.ucar.edu/ climate-data/nino-sst-indices-nino-12-3-34-4-oni-and-tni,

last access: 3 September 2020). The SAM Index used in this study is the Marshall Index (Marshall, 2003; available from https://legacy.bas.ac.uk/met/gjma/sam.html, last access: 3 September 2020). The IOD Index used in this study is the Dipole Mode Index (Saji et al., 1999; available from http://www.jamstec.go.jp/aplinfo/sintexf/iod/dipole_mode_ index.html, last access: 3 September 2020). The ENSO, SAM, and IOD indices were detrended (as were the corresponding accumulation and sea salt time series) to reduce the interference of any climate change signal or long-term trends and ensure any significance was due to interannual variability, rather than (for example) the pronounced shift toward the positive SAM phase during austral summer in recent decades (Marshall, 2003; Thompson et al., 2000).

\subsection{Reanalysis and model data}

To investigate atmospheric processes leading to the preservation of any climate signals, KNMI Climate Explorer (see https://climexp.knmi.nl/start.cgi, last access: 8 April 2021) was used to create composite maps of SST, zonal winds, and geopotential height anomalies during the upper and lower terciles of sea salt years in the MBS site and LD records. These fields were detrended in order to focus on the interannual variability of the climate modes. The SST anomalies were constructed using the HadISST observational dataset. The zonal wind and geopotential height anomalies were constructed using the ERA5 reanalysis dataset, which has an improved grid resolution $\left(0.25^{\circ} \times 0.25^{\circ}, \sim 27 \times 10 \mathrm{~km}\right.$ at MBS) compared to the commonly used ERA-Interim $\left(0.75^{\circ} \times 0.75^{\circ}\right.$, Tetzner et al., 2019). Zonal wind at $500 \mathrm{hPa}$ (instead of surface zonal winds) was chosen to reduce the influence of katabatic winds and topography. The $p$ values used for hypothesis significance testing were computed to indicate regions where anomalies are significant at the $90 \%$ level. The composite years were based on anomalous sea salt years, while the months displayed were chosen based on months that had significant correlations with the relevant climate modes.

To determine the reliability of the snow accumulation rates derived from the independent layer counting, the accumulation rates for the MBS ice cores were compared to the annual snowfall precipitation from ERA5. The weighted average precipitation from the four neighbouring geographic pixels was used to represent accumulation at the MBS ice core site (see Fig. A4). As high wind speeds can remove snow, we also sought to determine whether snowfall precipitation from ERA5 would be a useful comparison to ice-core-derived accumulation in the first case. Guided by the findings of $\mathrm{Li}$ and Pomeroy (1997), who determined a dry snow saltation wind speed threshold of $7.7 \mathrm{~m} \mathrm{~s}^{-1}$, we used coincident ERA5 near-surface wind to investigate the presence of a threshold for wind removal of fresh snow. We computed the correlation between annual total ice core accumulation and annual total ERA5 precipitation occurring during times when the wind speed was lower than a particular threshold. We performed this sensitivity test for a range of wind speeds from 0 to $30 \mathrm{~m} \mathrm{~s}^{-1}$. We also used the surface mass balance output from the Modele Atmospherique Region (MAR; Gallee and 
Schayes, 1994) to infer the climatology of snow net accumulation. MAR is a regional climate model, specifically developed for representing the climate of polar ice sheets, that improves the representation of the stable boundary layers and feedbacks with snow through sublimation and erosion and deposition processes. We used version 3.11 of MAR, which has a $35 \times 35 \mathrm{~km}^{2}$ horizontal resolution over the Antarctic domain and is driven by the ERA5 reanalysis at the boundary conditions (see Kittel et al., 2021, for more details on the Antarctic set-up and description of the model version). MAR has been thoroughly evaluated against meteorological observations and surface mass balance values over the Antarctic ice sheet (Agosta et al., 2019; Kittel et al., 2021). MAR better reproduces sublimation of precipitation in the katabatic layer over the coastal region (Grazioli et al., 2017), which is likely underestimated in the atmospheric layers of RACMO (Agosta et al., 2019). We preferenced MAR to RACMO, as Vance et al. (2016) showed that RACMO (version 2.1/ANT) underestimated surface mass balance in the MBS region. We use MAR monthly and 3-hourly surface mass balance interpolated using a four-nearest inverse-distance-weighted method at the MBS ice core site.

\section{Results}

\subsection{MBS and LD dating, snow accumulation, and sea salt concentrations}

The standard deviations of $\delta^{18} \mathrm{O}$ for repeated measurements of laboratory reference water samples are less than $0.07 \%$ o (for the LD ice core) and $0.05 \%$ (for the MBS ice cores). The MBS site record has a lower mean sample resolution and accumulation (15 samples per year, $0.296 \pm 0.06 \mathrm{~m} \mathrm{yr}^{-1}$ IE, and sample sizes of $3 \mathrm{~cm}$ ) compared to the LD record (24 samples per year, $0.747 \pm 0.15 \mathrm{~m} \mathrm{yr}^{-1} \mathrm{IE}$, and sample sizes of $5 \mathrm{~cm}$ ) over the period 1975-2016. The currently analysed section of the Charlie ice core covers the period 1975-2016 (21.31 m depth), the Alpha core covers 1979-2016 (19.88 m depth), and the Main core covers 1975-2007 (21.21 m depth, extends back likely 1000 years; however, only the upper section has been dated at this stage and is thus considered here). The new short LD ice core (that extends the satelliteera record) covers the period 1990-2016 (drilled to $28.37 \mathrm{~m}$ from the snow surface in summer 2017), meaning that it replaces and extends the four short ice cores used in Vance at al. (2013). A peak in nssSO ${ }_{4}^{2-}$ recorded in the MBS ice cores aligns with the reference horizon for the Pinatubo eruption, which occurred in mid-1991 (Plummer et al., 2012). Figure 2 shows the MBS cores presented here have reference horizons attributed to the Pinatubo eruption in late 1991 (Alpha) and in 1992 (Charlie and Main). Prior to this volcanic signature are 4-5 years where the annual horizons are harder to discern (e.g. 1986-1990).

The mean annual snow accumulation rates determined in the Alpha, Charlie, and Main ice cores are $0.298 \pm 0.07$,
$0.295 \pm 0.08$, and $0.309 \pm 0.08 \mathrm{~m} \mathrm{yr}^{-1}$ IE, respectively. The accumulation rates in the three MBS ice cores are significantly correlated in all cases, and these correlations increase after smoothing (see table insert in Fig. 3). The MBS Alpha and MBS site accumulation records are significantly correlated with the LD accumulation record (see table insert in Fig. 3). The ERA5 estimate of annual snow accumulation rate for the MBS site record is $0.302 \pm 0.05 \mathrm{~m} \mathrm{yr}^{-1}$ IE, while the MAR estimate of annual snow accumulation is $0.314 \pm 0.05 \mathrm{~m} \mathrm{yr}^{-1}$ IE. The sensitivity test indicated that the annual precipitation derived from ERA5 correlated most highly with ice core accumulation when the threshold for wind saltation was set very high (i.e. the net effect of wind distribution is close to zero at MBS), and again this indicates the success of the comprehensive study undertaken to determine the site selection for MBS (Vance et al., 2016). The degree of correlation between the accumulation in the MBS ice cores with ERA5 and MAR accumulation estimates are high and significant, with the exception of Charlie, especially when considering the independence of the two techniques (atmospheric reanalysis-derived site average versus independent layer counting; see table insert in Fig. 3). The ERA5 and MAR accumulation estimates suggest 2 consecutive years of low accumulation may have occurred in sequence (e.g. 1993 and 1994), which is not demonstrated in the layer-counted data (see Fig. 3). Figure 4 shows that the climatology of the ERA5 and MAR accumulation estimates at MBS have a relatively uniform distribution on average, peaking in austral winter (29\% and $34 \%$ of accumulation occurs during this season, respectively), followed by autumn ( $28 \%$ and $28 \%$ ), spring ( $23 \%$ and $27 \%$ ), and summer (20\% and $11 \%)$. Months with extreme precipitation and surface mass balance can occur in any season (see Fig. 4). There are 6 months over the period 1979-2016 with negative surface mass balance values. These all occur during summer, including January 1979, 1992, 1993 and December 1979, 1991, and 1994. Of note are the coincident summertime negative surface mass balance estimates with the previously identified and difficult to date low accumulation years of 1993 and 1994.

The mean annual sea salt concentrations in the Alpha, Charlie, and Main ice cores and the MBS site record are $1.085 \pm 0.32,1.052 \pm 0.38,1.118 \pm 0.36$, and $1.090 \pm 0.31 \mu \mathrm{Eq} \mathrm{L}^{-1}\left(\mu \mathrm{EqL}^{-1}\right.$ : micro-equivalents per litre), respectively, while the mean annual sea salt concentration in the LD record is $3.280 \pm 1.32 \mu \mathrm{EqL}^{-1}$. The $\mathrm{Na}^{+}$ and $\mathrm{Cl}^{-} \mathrm{MBS}$ data streams are essentially indistinguishable $(r=0.940, p<0.000)$. The annual log-transformed sea salt concentrations from the three MBS ice cores and the LD record are not significantly correlated, although the annual sea salt concentrations in the three MBS ice cores and the summer sea salt concentrations from the LD record are significantly (and negatively; see table insert in Fig. 5) correlated. The correlations between the MBS ice cores increase after smoothing (see table insert in Fig. 5). The sea salt con- 


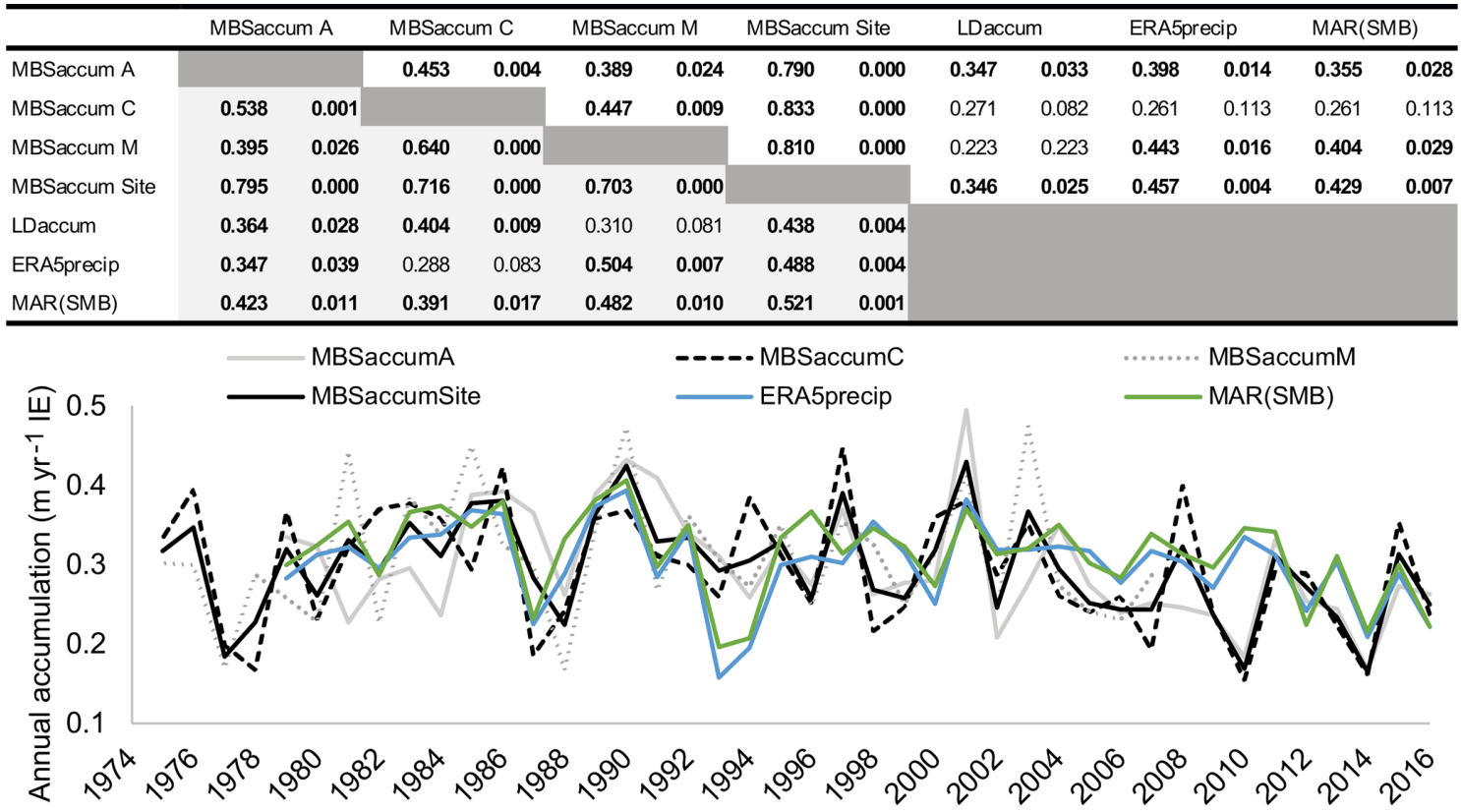

Figure 3. Time series of annual snow accumulation for the Mount Brown South site average (MBSaccumSite); the Alpha (MBSaccumA), Charlie (MBSaccumC), and Main (MBSaccumM) ice cores; and the ERA5 precipitation data from the MBS Main site (ERA5precip). The embedded table shows Pearson's correlation coefficient ( $r$ : left column; $p$ : right column) for the average annual snow accumulation for MBSaccumSite, MBSaccumA, MBSaccumC, and MBSaccumM and the annual snow accumulation for the Law Dome (Dome Summit South site) record (LDaccum). Correlations using Gaussian-smoothed (kernel $=3$ yearly points; $\sigma=0.6$ ) accumulation time series are shaded and presented in the lower-left of the table. Correlations significant at $95 \%$ are bold, and the dates range between 1975 and 2016.

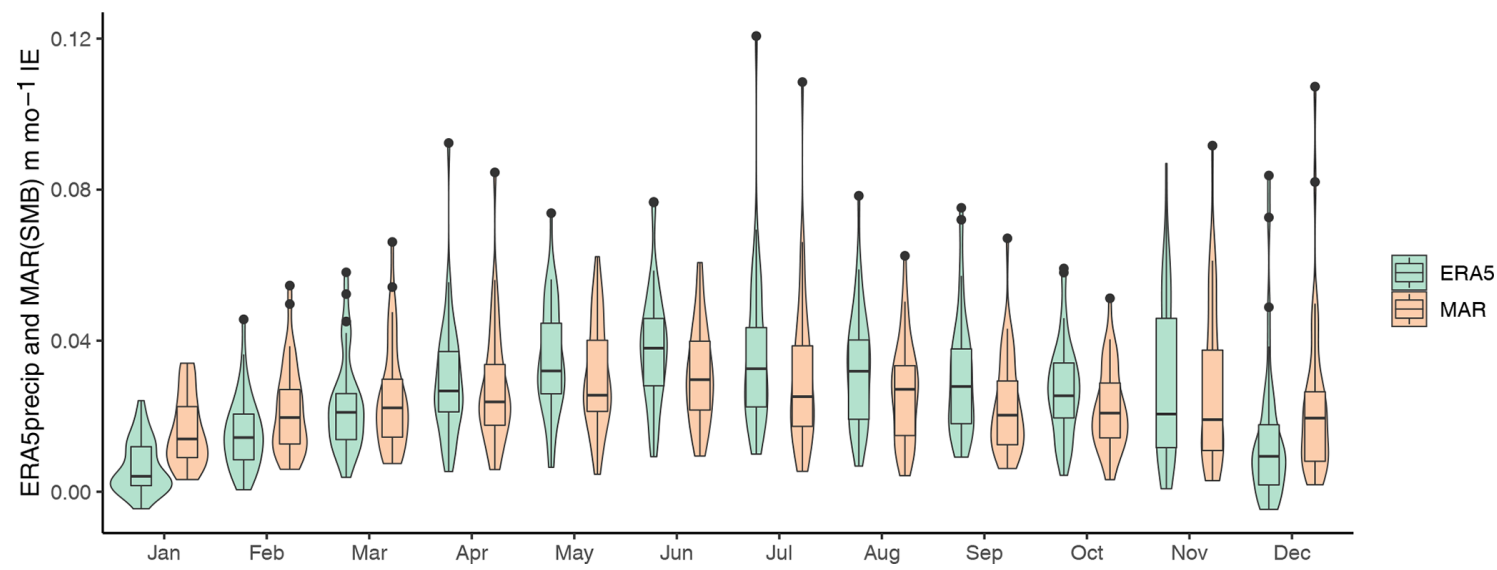

Figure 4. Climatology of surface mass balance and precipitation estimates at Mount Brown South from the Modele Atmospherique Regional (MAR(SMB)) and ERA5 (ERA5precip), respectively, over the period 1975-2016.

centration for the year 1987 in the MBS Charlie ice core was excluded from this study (see red dot in time series in Fig. 5), as it was difficult to discern a year horizon in 1988 in this core. Further investigation and possible reanalysis of the chemistry data for this year in this core is required before including this data in future analyses. The climatology of sea salt at MBS and LD are similar, with a peak in austral winter and spring (see Fig. A3).

\subsection{Climate signals in the MBS and LD ice cores}

The MBS sea salt site record is significantly correlated with the seasonal Multivariate ENSO Index, Niño 4, Niño 3.4, and the Southern Oscillation Index (June-November; see Table 1). Note that we repeated these correlation analyses using $\mathrm{Na}^{+}$instead of $\mathrm{Cl}^{-}$for the MBS site record, which produced virtually identical results (see Table A1). The LD summer sea salt record is also significantly correlated with the seasonal Niño 4, Niño 3.4 (September-November), and 


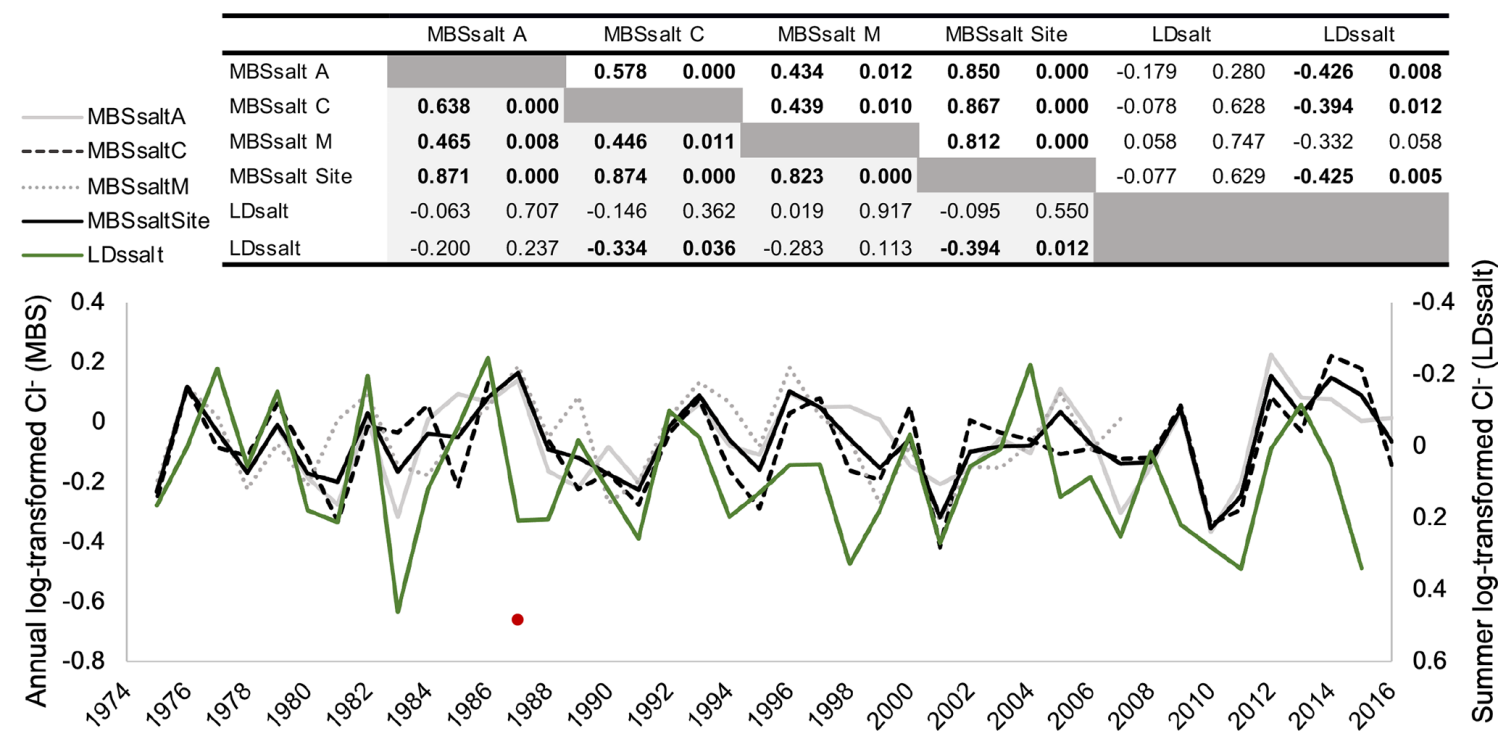

Figure 5. Time series of log-transformed annual sea salt concentrations for the Mount Brown South site average (MBSsaltSite), the Alpha (MBSsaltA), Charlie (MBSsaltC), and Main (MBSsaltM) ice cores, including the Charlie 1987 (red dot) outlier, and the log-transformed summer sea salt concentrations for the Law Dome (Dome Summit South site; LDssalt) record (on inverted secondary axis). The embedded table shows Pearson's correlation coefficient ( $r$ : left column; $p$ : right column) for the log-transformed sea salt concentrations for MBSsaltSite, MBSsaltA, MBSsaltC, MBSsaltM, LDssalt, and the log-transformed annual sea salt concentrations for the Law Dome (LDsalt) record. Correlations for normalized Gaussian-smoothed (kernel $=3$ yearly points; $\sigma=0.6$ ) sea salt concentrations are shaded and presented in the lower-left of the table. Correlations significant at $95 \%$ are bold, and the dates range between 1975 and 2016.

Southern Oscillation Index (November-February; see Table 1). The MBS-ENSO correlation (positive correlation with SST indices) is higher and more significant compared to the LD-ENSO correlation (negative correlation with SST indices). For example, the highest $r$ value between the annual MBS sea salt site record and the June-November ENSO Index is $r=0.533$ and $p=0.001$ (Multivariate ENSO Index), whereas the highest $r$ value between the summer LD sea salt record and the November-February ENSO Index is $r=0.398$ and $p=0.01$ (Southern Oscillation Index). Figure 6 shows that peaks (troughs) in the MBS sea salt site record generally correspond with peaks (troughs) in the Niño 3.4 Index, and the scatter plot therein shows that extreme anomalies (i.e. ENSO events) are reasonably well represented by the MBS sea salt site record.

Composite maps of SST anomalies in June-November based on high (low) MBS sea salt years indicate significant warming (cooling) of the central and eastern equatorial $\mathrm{Pa}$ cific (see Fig. 7b and d). Composite maps in NovemberFebruary based on the summer LD sea salts indicate an opposite trend in SST anomalies (i.e. warming (cooling) in the central and eastern equatorial Pacific during the low (high) LD summer sea salt years); however, these anomalies are not significant (see Fig. 7a and c). Composite map of geopotential height anomalies at $500 \mathrm{hPa}$ in June-November based on high MBS sea salt years corresponds with a significant weakening of the Amundsen Sea Low (see Fig. 8b), while low sea salt concentration years correspond with a signif- icant strengthening of the Amundsen Sea Low (note this anomaly is shifted toward the west; see Fig. 8e). Composite maps in November-February based on the LD record indicate a significant opposite pattern in geopotential height anomalies (i.e. strengthening (weakening) of the Amundsen Sea Low during the high (low) LD summer sea salt concentration years; see Fig. 8a and d). Composite maps based on the Niño 3.4 Index (see Fig. 8c and f) show similar geopotential height anomalies to those based on the MBS site record, although they are stronger and more widespread.

Figure 9 shows composite anomaly maps of the $10 \mathrm{~m}$ wind in June-August (austral winter) and September-November (spring) based on high and low sea salt years, along with maps of the mean $10 \mathrm{~m}$ wind. The prevailing wind direction in the MBS region is from the south-east in these seasons (see Fig. 9a and b). A feature of the winter pattern for the low and high sea salt years (see Fig. 9e and c, respectively) is the strong circulation changes north of the MBS region at around $60^{\circ} \mathrm{S}$. In winter during low sea salt years (see Fig. 9e), there is a weakening of the prevailing westerly flow associated with general circulation around an anomalous cyclonic feature to the north of MBS and an anomalous strengthening of the prevailing easterlies closer to the MBS site. In winter during high sea salt years (see Fig. 9c), there is a strengthening of the prevailing westerly flow around an anomalous anti-cyclonic feature and an anomalous weakening of the polar easterlies centred over the ice edge in winter. In spring, the off-shore and on-shore patterns are weaker 
Table 1. Pearson's correlation coefficient for the detrended accumulation (MBSaccumSite) and detrended annual log-transformed sea salt concentrations for the Mount Brown South site average (MBSsaltSite) and the detrended summer log-transformed sea salt concentration (LDssalt) for the Law Dome (Dome Summit South site) record against detrended seasonal ENSO, SAM, and IOD indices. Correlations significant at $95 \%$ are bold, and the dates range between 1975-2016.

\begin{tabular}{|c|c|c|c|c|c|}
\hline & & Seasonal indices & Range & $r$ value & $p$ value \\
\hline \multirow[t]{10}{*}{ MBSsaltSite } & ENSO (Multivariate ENSO Index) & JJASON & 1979-2016 & 0.533 & 0.001 \\
\hline & ENSO (4 Index) & JJASON & 1975-2016 & 0.521 & 0.000 \\
\hline & ENSO (3.4 Index) & JJASON & 1975-2016 & 0.457 & 0.002 \\
\hline & ENSO (Southern Oscillation Index) & JJASON & 1975-2016 & -0.496 & 0.001 \\
\hline & SAM (Marshall Index) & DJF (January year) & 1975-2016 & 0.107 & 0.498 \\
\hline & SAM (Marshall Index) & MAM & 1975-2016 & 0.274 & 0.079 \\
\hline & SAM (Marshall Index) & JJA & 1975-2016 & 0.175 & 0.266 \\
\hline & SAM (Marshall Index) & SON & 1975-2016 & -0.168 & 0.287 \\
\hline & SAM (Marshall Index) & DJF (December year) & 1975-2016 & -0.203 & 0.196 \\
\hline & IOD (Dipole Mode Index) & SON & 1975-2016 & 0.231 & 0.140 \\
\hline \multirow[t]{6}{*}{ LDssalt } & ENSO (Multivariate ENSO Index) & SON & 1979-2016 & -0.287 & 0.073 \\
\hline & ENSO (4 Index) & SON & 1975-2016 & -0.347 & 0.026 \\
\hline & ENSO (3.4 Index) & SON & 1975-2016 & -0.332 & 0.034 \\
\hline & ENSO (Southern Oscillation Index) & NDJF & 1975-2016 & 0.398 & 0.010 \\
\hline & SAM (Marshall Index) & DJFM & $1975-2016$ & 0.270 & 0.087 \\
\hline & IOD (Dipole Mode Index) & SON & 1975-2016 & -0.122 & 0.449 \\
\hline \multirow[t]{10}{*}{ MBSaccumSite } & ENSO (Multivariate ENSO Index) & JJASON & 1979-2016 & 0.226 & 0.173 \\
\hline & ENSO (4 Index) & JJASON & 1975-2016 & 0.213 & 0.175 \\
\hline & ENSO (3.4 Index) & JJASON & 1975-2016 & 0.147 & 0.353 \\
\hline & ENSO (Southern Oscillation Index) & JJASON & $1975-2016$ & -0.104 & 0.511 \\
\hline & SAM (Marshall Index) & DJF (January year) & $1975-2016$ & 0.150 & 0.342 \\
\hline & SAM (Marshall Index) & MAM & $1975-2016$ & 0.065 & 0.684 \\
\hline & SAM (Marshall Index) & JJA & 1975-2016 & 0.043 & 0.787 \\
\hline & SAM (Marshall Index) & SON & 1975-2016 & 0.159 & 0.313 \\
\hline & SAM (Marshall Index) & DJF (December year) & 1975-2016 & -0.145 & 0.361 \\
\hline & IOD (Dipole Mode Index) & SON & 1975-2016 & 0.148 & 0.348 \\
\hline
\end{tabular}

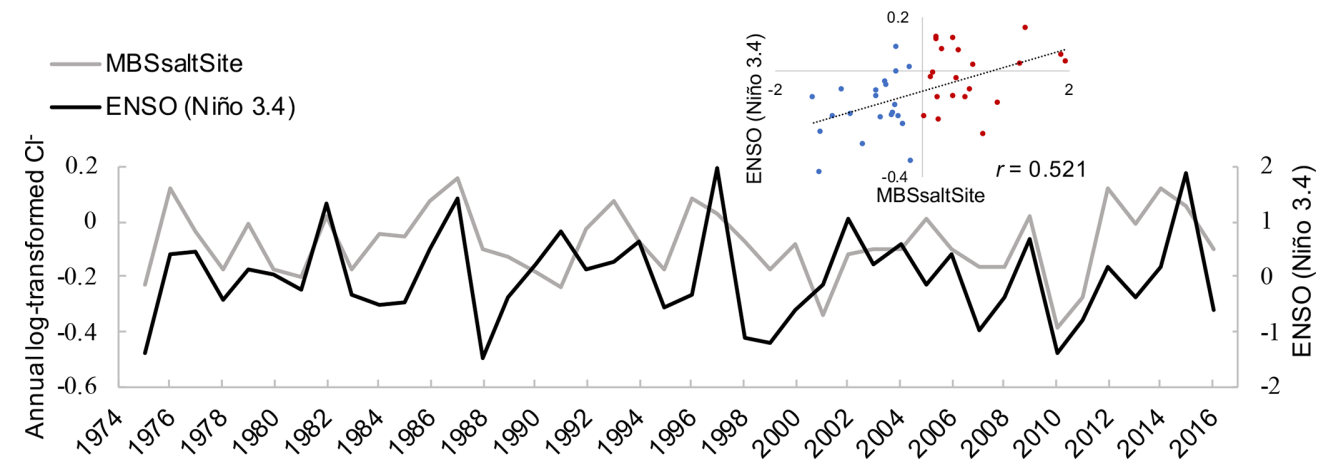

Figure 6. Time series of the annual detrended, log-transformed sea salt concentrations for the Mount Brown South site average (MBSsaltSite) and the detrended (June-November) El Niño-Southern Oscillation region SST anomalies (ENSO, Niño 3.4 Index). The embedded scatter plot shows the relationship between the two time series differentiated by positive (red dots) and negative (blue dots) Niño 3.4 region SST anomalies based on the period 1975-2016.

(see Fig. 9d and f) and their potential influence on frontal passages is less clear.

Table 1 shows that the annual accumulation records from the MBS site and LD records are not significantly correlated with any of the climate mode indices investigated here. The
MBS site and LD sea salt records are also not significantly correlated with the spring IOD (Dipole Mode Index) or the seasonal MBS and December-March LD SAM (Marshall Index, see Table 1). Despite the lack of a statistically significant SAM signal in the annual MBS sea salt site record, com- 
(a) LD

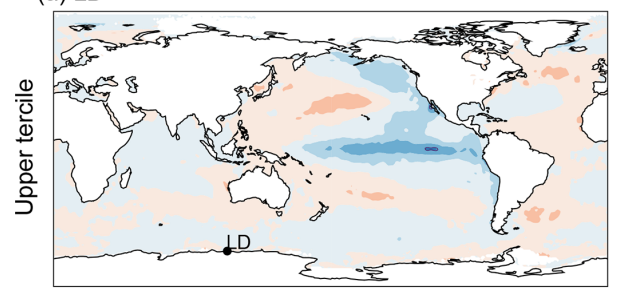

(b) MBS

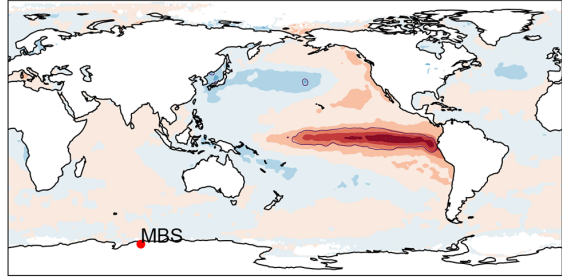

(c) LD

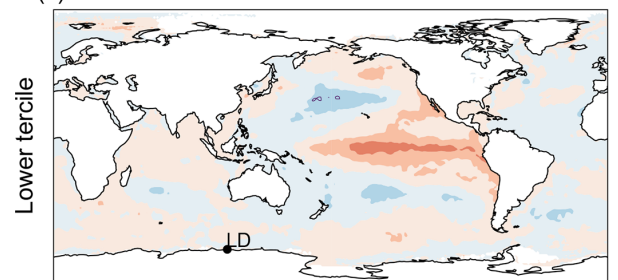

(d) MBS

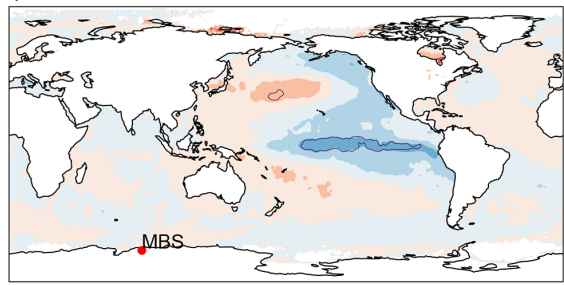

${ }^{\circ} \mathrm{K}-0.8$

Figure 7. SST anomaly composite maps during the upper (a) and lower (c) tercile (November-February) of the detrended, log-transformed summer sea salt concentrations from the Law Dome (LD, Dome Summit South site) record over 1975-2015, and upper (b) and lower (d) tercile (June-November) detrended, log-transformed sea salt concentrations from the annual Mount Brown South (MBS) site average over 1975-2016. The red dot indicates MBS, and the black dot indicates LD. Significant anomalies are within the upper and lower purple contour lines, where $p<0.1$.

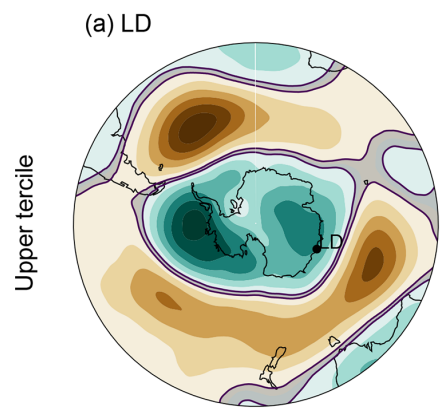

(b) MBS

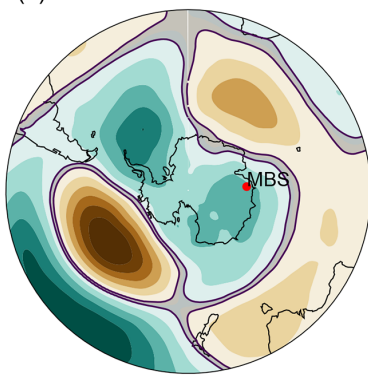

(e) MBS
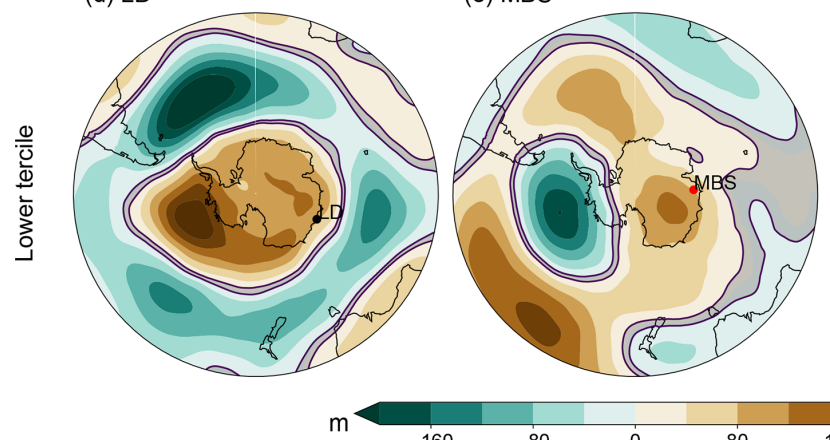

(c) Niño 3.4

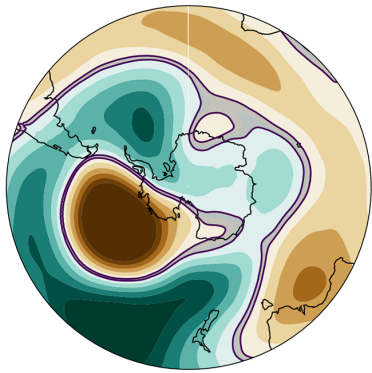

(f) Niño 3.4

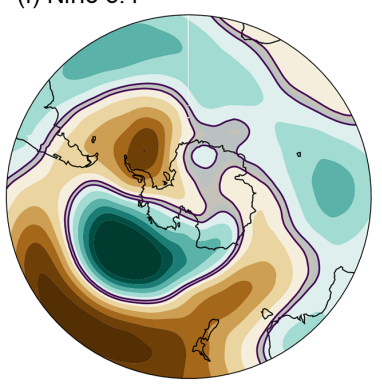

60

Figure 8. Geopotential height composite anomaly maps (metres at Z500) during the upper (a) and lower (d) tercile (November-February) of the detrended, log-transformed summer sea salt concentrations from the Law Dome (LD, Dome Summit South site) record over 1979-2015. (b, e) The same as (a) and (d) except using the detrended, log-transformed annual sea salt concentrations from the Mount Brown South (MBS) site average (June-November) over the period 1979-2016. (c, f) The same as (b) and (e) except using the detrended Niño 3.4 Index (June-November). The red dot indicates MBS, and the black dot indicates LD. Significant anomalies are within the upper and lower purple contour lines, where $p<0.1$. 
(a) Mean (JJA)

(b) Mean (SON)

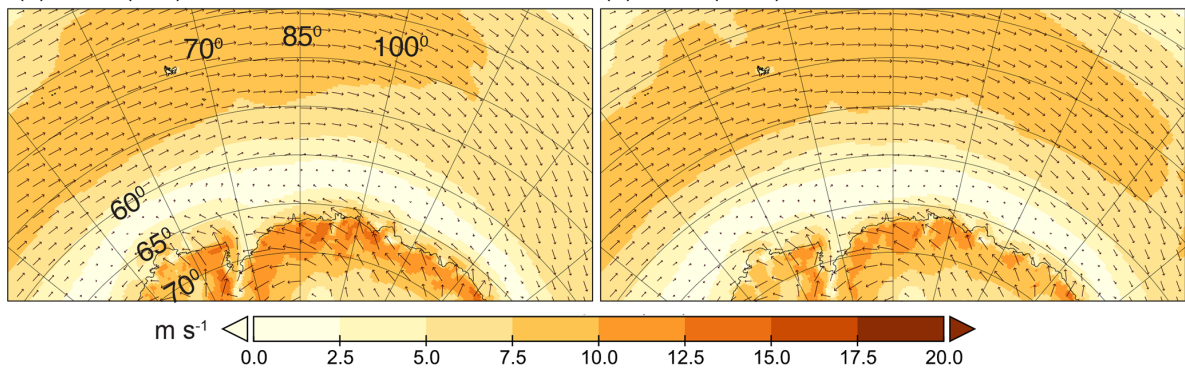

(c) MBS (JJA) upper tercile

(d) MBS (SON) upper tercile
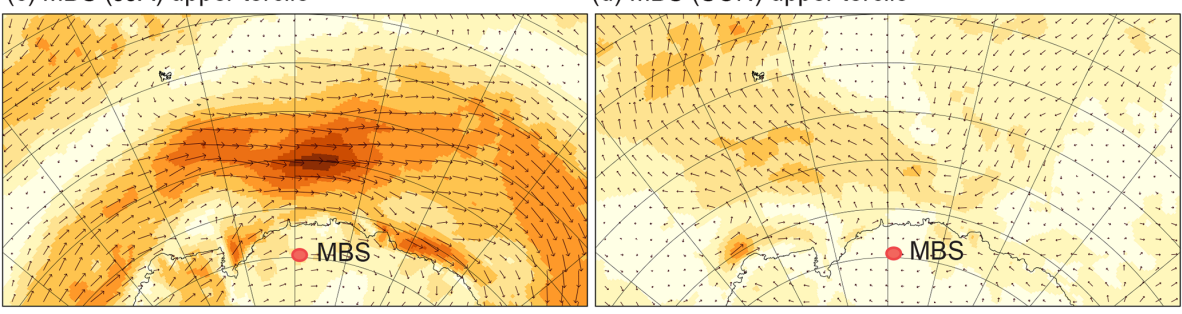

(e) MBS (JJA) lower tercile

(f) MBS (SON) lower tercile

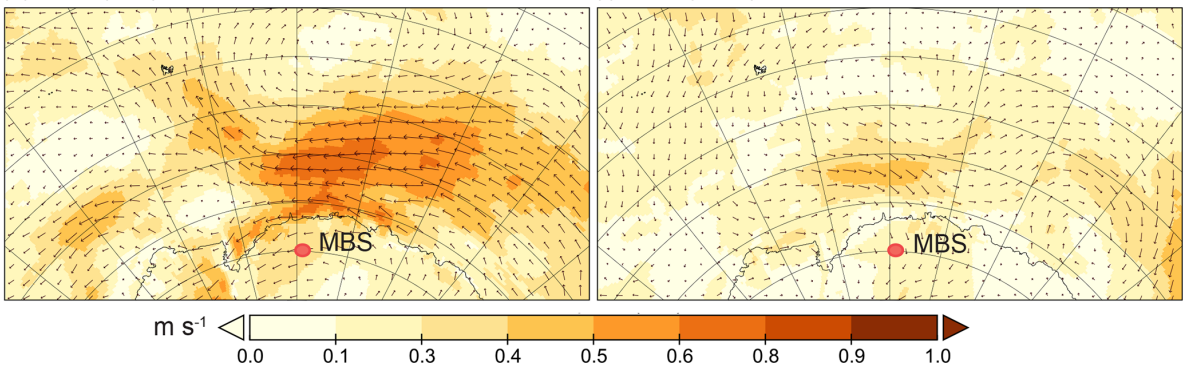

Figure 9. Near-surface $(10 \mathrm{~m})$ wind vector composite maps of the mean state during austral winter (a, June-August) and spring (b, September-November) and anomaly composite maps during the upper (c) and lower (e) tercile in June-August of the detrended, logtransformed annual sea salt concentrations from the Mount Brown South (MBS) site average, over the period 1979-2016. (d, f) The same as (c) and (e) except in September-November. The red dot indicates the MBS site location. Latitudinal lines are in increments of $5^{\circ}$, and longitudinal lines are in increments of $15^{\circ}$.

posite maps show SAM-like patterns in $500 \mathrm{hPa}$ zonal wind anomalies during austral summer (see Fig. 10b and e). Composite maps in December-February based on low MBS sea salt years indicate a significant enhancement of zonal wind anomalies in the high latitudes and a coincident reduction in the mid-latitudes (see Fig. 10e). The inverse is true for composite maps based on the high MBS sea salt years, with a significant reduction of zonal wind anomalies in the high latitudes and enhancement in the mid-latitudes, although the reduction in high-latitude zonal wind anomalies is not symmetrical across the Southern Hemisphere (see Fig. 10b). Composite maps in November-February based on the LD summer sea salt years indicate an opposite and significant pattern in zonal wind anomalies (i.e. enhancement (reduction) of zonal wind anomalies in the high- (mid-) latitudes during lower tercile LD sea salt years (see Fig. 10d), and vice versa for upper tercile sea salt years (see Fig. 10a). Composite maps based on the SAM Marshall Index (see Fig. 10c and f) show opposite zonal wind anomalies to those based on the MBS site record, although with a more zonally symmetric pattern in the upper tercile years.

\section{Discussion}

\subsection{MBS and LD ice core features 1975-2016}

The currently dated recent portion of the MBS site record fulfils the requirements stated by Vance et al. (2016) of having an annual snow accumulation rate of at least 0.200 $0.250 \mathrm{~m} \mathrm{yr}^{-1} \mathrm{IE}$ and a strong teleconnection with the low latitudes and mid-latitudes and (based on the initial surface accumulation rate analysis presented here) will likely date back 1000 years at $300 \mathrm{~m}$ depth. The mean accumulation rate at MBS is identical to the findings of Foster et al. (2006; $0.297 \mathrm{~m} \mathrm{yr}^{-1}$ IE over the period 1984-1999), higher than the findings of Smith et al. (2002; $0.255 \mathrm{~m} \mathrm{yr}^{-1} \mathrm{IE}$, has a range of 10 years of accumulation over the period 1979-1998), and is higher than estimated in Vance et al. (2016; 0.200 $0.250 \mathrm{~m} \mathrm{yr}^{-1} \mathrm{IE}$ ), suggesting that RACMO (used in Vance et 
(a) LD

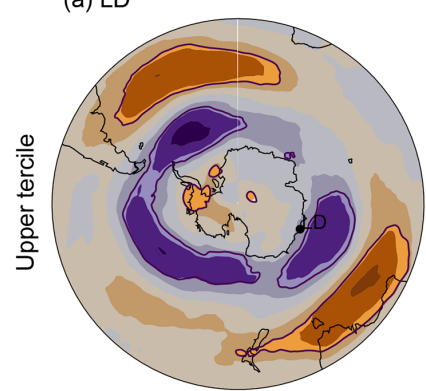

(d) LD

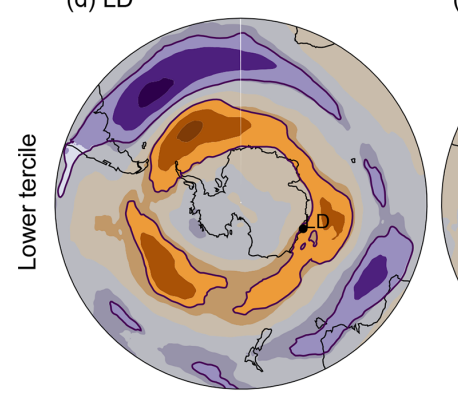

(b) MBS

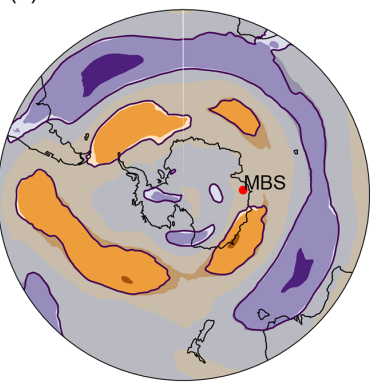

(c) Marshall

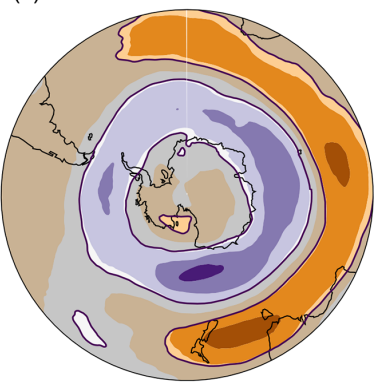

(f) Marshall

(e) MBS
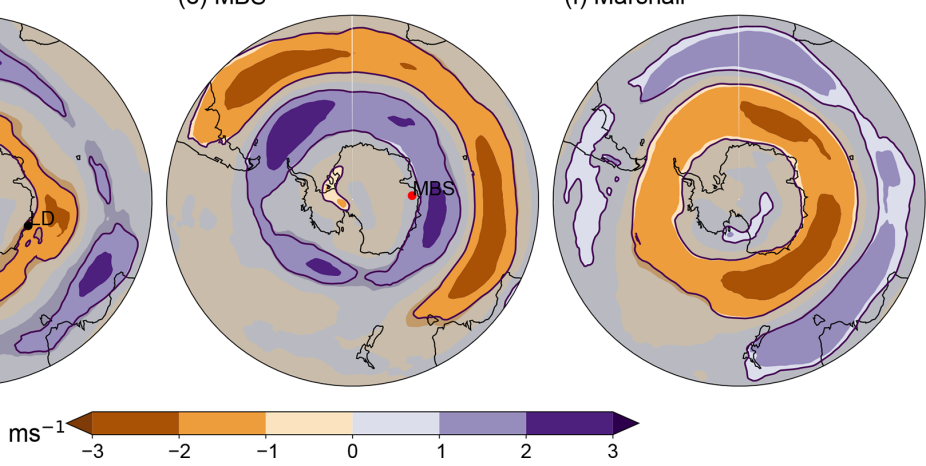

Figure 10. Zonal wind anomaly composite maps $\left(\mathrm{m} \mathrm{s}^{-1}\right.$ at $\left.500 \mathrm{hPa}\right)$ during the upper (a) and lower (d) tercile (November-February) of the detrended, log-transformed summer sea salt concentrations from the Law Dome (LD, Dome Summit South site) record over the period 1979-2015. (b, e) The same as (a) and (d) except using the detrended, log-transformed annual sea salt concentrations from the Mount Brown South site average (MBS, December-February) over the period 1979-2016. (c, f) The same as (b) and (e) except using the detrended SAM Marshall Index (December-February). The red dot indicates MBS, and the black dot indicates LD. Significant anomalies are within the upper and lower purple contour lines, where $p<0.1$.

al., 2016) does in fact underestimate net surface mass balance in this region. There is some variability in individual accumulation years between the MBS ice cores but not enough to suggest that the relatively large sastrugi and drifts (as high as $0.5 \mathrm{~m}$, i.e. more than the annual accumulation rate derived for MBS) observed at the site in 2017/2018 during drilling are a common feature at the site on interannual timescales (see Figs. A1 and A2). The mean accumulation rate in the new LD record presented here $\left(0.747 \pm 0.15 \mathrm{~m} \mathrm{yr}^{-1} \mathrm{IE}\right)$ is higher than presented in Morgan et al. (1997; $0.678 \mathrm{~m} \mathrm{yr}^{-1}$ ), Roberts et al. (2015; $\left.0.688 \mathrm{~m} \mathrm{yr}^{-1}\right)$, and van Ommen and Morgan (2010; $\left.0.688 \mathrm{~m} \mathrm{yr}^{-1}\right)$; however, these studies focus on centennial-scale periods, and in fact a higher accumulation rate at LD in recent decades compared to the longerterm average is supported by the findings of van Ommen and Morgan (2010) and Medley and Thomas (2018). The climatology of sea salt concentrations in the MBS site record and updated LD record are comparable with the LD record presented in Curran et al. (2003) and likely result from increased mid-latitude storminess during winter (Goodwin et al., 2004). However, the lower sample resolution in the MBS site record and the potential for seasonal variability in snow accumulation identified in this work mean that the climatology of sea salts should be interpreted with caution until the periodicity of snowfall events at MBS is determined in greater detail and a longer record is developed.

The lower accumulation rate in the MBS site record compared to the LD record means that MBS may incur more dating errors if specific seasonally varying species, such as water stable isotopes, are not preserved. However, the high $r$ values between the ERA5 and MAR accumulation estimates and the snow accumulation time series from independently dated MBS ice cores suggest that the dating is reliable, at least during the period examined here (1975-2016). The interim dating of the MBS ice cores via independent layer counting shown in this work has not been corrected with reference to the ERA5 or MAR data. This means we can use the comparison with ERA5 and MAR to determine how and why independent layer counting may result in dating errors in the longer record as it is produced. This is an important first step to understanding how dating errors in the long layer-counted MBS ice core may develop and propagate. In both the MBS and $\mathrm{LD}$ records we assume the correct date for the Pinatubo reference horizons is likely to be late 1991-1993, as extensive examination over multiple overlapping records of the Pinatubo eruption has been undertaken previously (Plummer et al., 2012). The difference in Pinatubo reference horizon years between the three MBS ice cores indicates the possi- 
bility of a 1-year dating error in the MBS composite records. Alternatively, it could be that the main body of the sulfate deposition for MBS occurred later at the Alpha MBS site, either because of interference by sastrugi or snow redistribution. Either way, additional analytes once available (e.g. hydrogen peroxide, dust, and tephra) may help reduce any dating errors from the interim suite of analytes available for layer counting in this study. Additional analytes may help to confirm the MBS ice core dating over the period 1986-1990, which contains isotopic and trace chemistry signatures that are at times ambiguous. This period is similarly difficult to date in multiple LD records and is likely due to a period of extensive atmospheric blocking that occurred in the southern Tasman Sea that led to warm intrusions of moisture (Pook and Gibson, 1999; Udy et al., 2021). Atmospheric blocking and subsequent moisture intrusions can deliver significant snowfall to specific regions of East Antarctica (Massom et al., 2004; Wille et al., 2019). Furthermore, we expect to be able to constrain dating more accurately once we have a longer dataset that spans the Tambora eruption (1815), which has a strong and consistent signal at LD; thus, we expect a similarly clear signal at MBS. The MBS site record preserves signals for the ENSO, indicating that the record does contain signals for past climate variability beyond the local climate conditions. The MBS site record differs from the LD record in annual sea salt concentrations and provides another independent climate record for the data sparse Indian Ocean sector of Antarctica, meaning that it fulfils the site selection criteria highlighted in Vance et al. (2016) of containing a record complementary to, but not the same as, LD. The inverse correlation between the sea salts from the annual MBS site record and summer LD record is interesting and requires further investigation.

\subsection{Preservation of the ENSO signal in the MBS and LD records}

The MBS site record captures strong ENSO events over the period 1975-2016, but it does not cover all events. For example, it captures the 1974/1975 and 2010/2011 La Niña events and the 1982/1983, 1987/1988, and 2009/2010 El Niño events, with corresponding troughs and peaks in the ENSO 3.4 Index (see Fig. 6). However, the extreme $1997 / 1998$ El Niño event is less clear, with a higher sea salt peak 1 year prior (see Fig. 6). The MBS site record contains a stronger signal for the ENSO compared to the LD record, including the LD record presented in Vance et al. (2013) ( $r=0.336 ; p<0.000)$ and the updated record presented here. The ENSO signal in the MBS site record is also not skewed in contrast to the LD record, which displays an asymmetry toward a representation of La Niña rather than El Niño events (Vance et al., 2013). It is difficult to directly compare the ENSO signals at MBS and LD because the MBS signal is based on annual sea salt concentrations, which are heavily influenced by winter storminess, whereas the LD signal is based on summer sea salt concentrations. The dating of annual sea salts is easier to constrain in a new record like MBS compared to the summer sea salt proxy from LD, which has been extensively studied allowing the assumption of uniform annual accumulation to define monthly LD boundaries.

Fully understanding the mechanisms behind the transport of the ENSO signal to MBS requires further analysis; however, preliminary analyses of oceanic and atmospheric processes suggest that the ENSO signal is robust. SST anomalies based on the MBS site record reflect patterns associated with El Niño and La Niña events and are supported by the correlation results (i.e. low sea salt concentration years occur during La Niña events and are associated with low SST anomalies in the equatorial Pacific, and vice versa). Geopotential height anomalies based on the MBS site record reflect patterns associated with El Niño and La Niña events, specifically changes in the strength of the Amundsen Sea Low. These patterns further support the reliability of the ENSO signal in the MBS site record. Opposite patterns in SST and geopotential height anomalies based on the MBS and LD records are expected, as these records are inversely correlated (note the annual MBS site versus summer LD records). It is unsurprising that the MBS record is related more strongly to atmospheric circulation anomalies that develop in austral winter than spring, as winter has higher precipitation and surface mass balance estimates based on the ERA5 and MAR data. In winter, frontal systems may transport regionally sourced sea salt aerosol via increases in surface wind speeds over the ocean (or from frost flowers forming on sea ice) from the north of MBS to the site. We suggest the ability of moisture-carrying sea salt aerosols to become advected over the MBS site may be weaker during low sea salt years and stronger during high sea salt years. Further analysis is required to determine how these teleconnections resulting from the ENSO manifest in the southern Indian Ocean north of the MBS site and whether brine-rich frost flowers contribute to the sea salt deposition at MBS. Concurrent work by Udy et al. (2021) found coherence between ENSO events and synoptic variability in the southern Indian Ocean during austral spring and summer. Specifically, this coherence related to synoptic types that had clear meridional structures and were related to blocking in the southern Indian Ocean, in contrast to synoptic types with a more zonal structure, hinting at the dynamic cause of the ENSO signals at MBS and LD.

It was observed during drilling in 2017/2018 that the sastrugi at MBS were aligned to approximately $80^{\circ}$ and $260^{\circ}$, suggesting the prevailing winds during the 2017/2018 austral summer were likely east-north-easterlies (see Fig. A2), although as mentioned before the surface features at the site in 2017/2018 summer may have been anomalous. If the prevailing winds at MBS are east-north-easterlies, it is possible that the maritime signal is less influenced by katabatic winds, and therefore the MBS site record may contain a stronger maritime signal compared to LD, at least in terms of moisture delivery to MBS. The prevalence of the maritime signal is also observed in the precipitation impact from atmospheric rivers, 
which provides a subtropical link to the Antarctic continent. Atmospheric rivers have been linked with extreme precipitation events in East Antarctica with implications for surface mass balance estimates (Gorodetskaya et al., 2014). Such extreme precipitation events also have a role in Antarctic snowfall variability (Turner et al., 2019; Wille et al., 2021). Atmospheric river landfalls across Antarctica are typically associated with a blocking ridge downstream (i.e. to the east) of the landfall location and intense meridional moisture fluxes (Gorodetskaya et al., 2014; Massom et al., 2004; Wille et al., 2021). Future work will focus on the influence of extratropical cyclones and their interactions with mid-latitude blocks on moisture intrusions (and sea salt transport) at both sites (e.g. following Gorodetskaya et al., 2014; Wille et al., 2019). Additional studies focusing on back trajectories of wind direction and speed and comparing these with previous backtrajectory studies (e.g. Scarchilli et al., 2011) and synoptictyping studies (e.g. Udy et al., 2021) are recommended to improve the quantitative interpretation of the MBS record.

\subsection{Lack of preservation of SAM and IOD signals in the MBS and LD records}

Although the annual MBS site record does not preserve a strong SAM signal, it is possible that refined dating in the future may allow for the investigation of a SAM signal using seasonal MBS sea salt records (as opposed to the annual record used here), as the SAM varies on a weekly to seasonal timescale (Marshall, 2003). Composite maps based on the MBS site record reflect SAM-like patterns in zonal wind anomalies (i.e. the contraction and the expansion of the westerly wind belt around the Antarctic continent; Marshall, 2003) in austral summer. This suggests that the MBS site may preserve signals of the SAM during summer, although in the currently dated record the surface mass balance is lowest during summer, meaning the likelihood of signal preservation during this season may be reduced. Note that these patterns in zonal wind anomalies are not dependent on the trend in summer SAM since 1958 (Marshall, 2003; Thompson et al., 2000), as both the Marshall Index and corresponding sea salts were detrended here. The new updated LD record does not preserve a SAM signal using the Marshall Index months presented in Vance et al. (2013), although the study here only compares ice core data to indices since 1975, in contrast to 1958-2009 in Vance et al. (2013). This may be due to differences in timing noise between individual ice cores that make up the record or may result from decadal variability in how the SAM signal is preserved (e.g. stronger relationship earlier in the index). The LD record is also skewed towards negative SAM-like years (i.e. low sea salt years), although this is expected as Marshall et al. (2017) suggest that the LD contains a skewed SAM signal, with increased precipitation in the LD region associated with the negative SAM phase.

Although the SAM-like patterns in zonal wind anomalies based on the MBS and LD record are approximately sym- metrical, there are multiple studies debating the symmetry of SAM. Fogt et al. (2012) suggest asymmetries in the SAM are related to the ENSO (in austral spring and summer) and the Zonal Wave 3 (in winter) and associated with shifts in the entrance and exit regions of the Antarctic jet stream in the South Pacific. Ding et al. (2012) suggest that the SAM signature in the Indian Ocean and South Pacific sectors of Antarctica differ. The authors describe the form of SAM in the Indian Ocean as an elongated meridional dipole due to strong internal dynamics, and the form of SAM in the South Pacific as a longitudinal band due to forcing from equatorial Pacific SST anomalies. Asymmetries in the SAM may be related to increased or decreased prevalence of blocking events, which may influence accumulation at MBS and LD, as blocking events control extreme moisture intrusion in the form of atmospheric rivers (Udy et al., 2021; Wille et al., 2019). Scott et al. (2019) suggest that El Niño and negative SAM conditions favoured blocking events in the Amundsen Sea, both leading to warm surface air anomalies in West Antarctica. Udy et al. (2021) define numerous meridional synoptic types in the southern Indian Ocean, which likely disrupt the annular structure of the SAM in this region on weekly to seasonal scales. The influence of warm, moist intrusions on East Antarctica is not well understood, and further atmospheric analyses in the southern Indian Ocean/MBS region may aid in explaining the ENSO teleconnection.

Despite the location of MBS in the central Indian Ocean sector of Antarctica, there is no statistically significant IOD signal in the MBS record. This is not overly surprising because the IOD is seasonally locked (peaking in spring), meaning that an IOD signal (if preserved) may only be preserved in the seasonal MBS record. Additionally, there are very limited data and literature on the influence of the IOD in the Antarctic region. In climate model simulations IOD activity in the tropical eastern Indian ocean excites Rossby wave trains in the atmosphere that propagate in a south-easterly direction, resulting in climate and sea ice anomalies focussed most strongly in the Amundsen and Bellingshausen seas region of West Antarctica (Abram et al., 2020; Nuncio and Yuan, 2015; Purich and England, 2019) rather than in the southern Indian Ocean sector. However, it is also debated whether or not continuous propagation of Rossby wave trains excited by IOD events are able to propagate as far as the Antarctic or if these wave trains are prohibited by the subtropical jet (McIntosh and Hendon, 2018). Together, all of these factors mean that it is unsurprising that a statistical relationship of IOD variability with the MBS annual mean ice core data is not found in this study.

\subsection{Robustness of the ENSO signal in the MBS record}

Although our results suggest a robust ENSO signal in the MBS site record, we acknowledge that the strength of this signal may vary over a longer timescale due to decadal variability. Although the record presented here is too short to in- 
vestigate decadal variability, the extended MBS Main record may be used in the future to determine any stationarity or non-stationarity of the ENSO signal and thereby aid in correctly interpreting the MBS record. A potential cause of non-stationarity may be the Interdecadal Pacific Oscillation, as this climate mode influences the southern Indian Ocean (Crueger et al., 2009), and hence the ENSO signal in the LD record (Vance et al., 2015). The Interdecadal Pacific Oscillation is a low-frequency climate oscillation (20-30 years) characterized by warm (cool) SST anomalies in the equatorial Pacific during the positive (negative) Interdecadal Pacific Oscillation phase (Power et al., 1999). It is debated whether the Interdecadal Pacific Oscillation is a low-frequency ENSO (Westra et al., 2015) or an independent climate mode (Newman et al., 2016). The interactions between these climate modes are not fully understood, although it is suggested that the Interdecadal Pacific Oscillation influences the strength and locality of the teleconnection between the equatorial Pacific and the southern high latitudes (Vance et al., 2013, 2015, 2016).

A better understanding of interactions between the ENSO and other climate modes in the southern Indian Ocean is important for correctly interpreting the ENSO signal in the MBS record, particularly in the extended MBS Main core. Multiple studies have documented interactions between the ENSO and SAM (e.g. Cai et al., 2011; Clem and Fogt, 2013; Dätwyler et al., 2020; Fogt et al., 2011; Gong et al., 2010; Kim et al., 2017; L'Heureux and Thompson, 2006; Lim et al., 2013; Yu et al., 2015). For example, a recent study by Dätwyler et al. (2020) looking at millennial timescale climate variability showed that the ENSO and SAM are significantly correlated during austral summer $(r=-0.3)$. This negative correlation arises when the ENSO and SAM are in phase (i.e. when El Niño-negative SAM or La Niña-positive SAM co-occur). When El Niño-negative SAM (La Niñapositive SAM) events coincide, storm tracks shift equatorward (poleward) resulting in the weakening (strengthening) of circumpolar westerly winds (Dätwyler et al., 2020). Fogt et al. (2011) suggest that the SAM modulates the ENSO teleconnection with the southern high latitudes. When the ENSO and SAM are in phase, transient eddies in the mid-latitudes are supportive, which reinforces the ENSO teleconnection. In contrast, when the ENSO and SAM are out of phase (i.e. when El Niño-positive SAM or La Niña-negative SAM cooccur), these transient eddies oppose each other, weakening the ENSO teleconnection. Furthermore, L'Heureux and Thompson (2006) show that the ENSO accounts for $25 \%$ of the temporal variability in the SAM during austral summer. Although the IOD is a distinct climate mode, ENSO events can trigger IOD events by altering atmospheric circulation (e.g. the Walker Circulation, Fischer et al., 2005; Guo et al., 2015). The ENSO and IOD are tightly linked; for example, Abram et al. (2020) show that these two climate modes have comparable interannual variability (in magnitude and timing) over the recent millennium. The authors relate this to varia- tions in SST gradients over the equatorial Pacific. Studies on the ENSO-SAM and ENSO-IOD interactions tend to focus on the West Antarctica region, with few investigating interactions in the Indian Ocean sector of the Southern Ocean adjacent to where MBS is located.

\section{Conclusion}

Here, we present the preliminary analysis of the upper portion of the new MBS ice cores and extend the LD record from 2009 to 2016 . The MBS site record fulfils its drilling requirements of being an annually dated, high-resolution record complementary to the LD record. The upper portion of the MBS ice core site record analysed here preserves a statistically significant signal for the ENSO (in austral winter and spring) in the annual sea salt concentrations. The ENSO signal in the MBS site record is stronger than that found in the LD record, including both the record presented in Vance et al. (2013) and the updated record presented here. Investigation into the environmental conditions leading to the preservation of the ENSO signal in the MBS site record indicates ENSO-like patterns in SST anomalies in the equatorial Pacific and changes in the strength of the Amundsen Sea Low. We suggest that surface wind anomalies to the north of MBS may control the production of sea salt aerosol (and hence deposition) near the MBS site, and thereby influence signal preservation of the ENSO. Although we focus on the period 1975-2016, based on the initial snow accumulation rate presented here, the full MBS Main ice core is likely to span the last millennium. When this extended MBS Main ice core is analysed and dated, the robustness of the ENSO signal will be further investigated. If this signal is robust, then a millennial-timescale ENSO proxy may be established and linked to regional variability in the southern Indian Ocean that will improve the reliability of past climate reconstructions and hence future climate projections. Future work will also investigate the potential signals of regional climate variability and whether a SAM or IOD signal is preserved in the seasonal MBS trace ion chemistry or extended snow accumulation records, as the SAM and IOD affect temperature and hydroclimate across the Southern Hemisphere continents. 


\section{Appendix A}

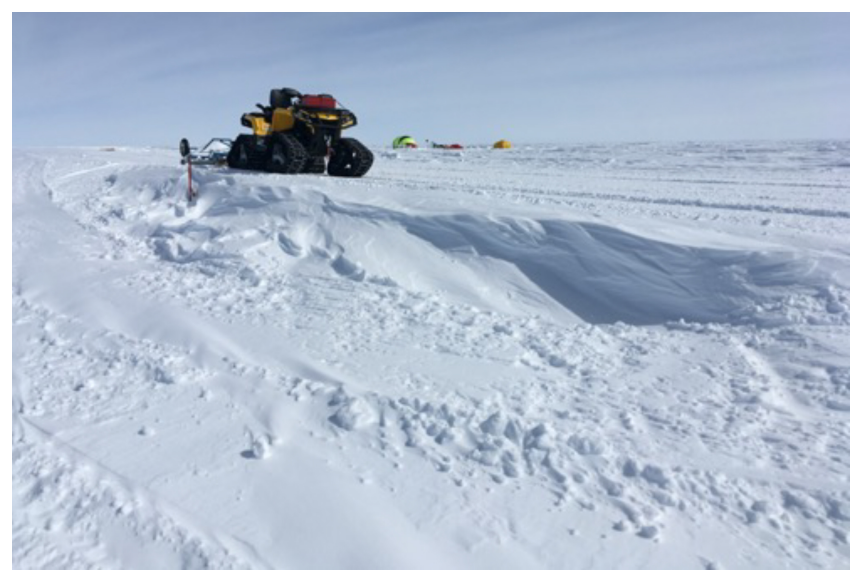

Figure A1. Sastrugi (as high as $0.5 \mathrm{~m}$ ) at Mount Brown South in East Antarctica during austral summer in 2017/2018. The height of the largest sastrugi is comparable with the annual mean snow accumulation rate over the period 1975-2016. Photo credit: Tessa Vance.

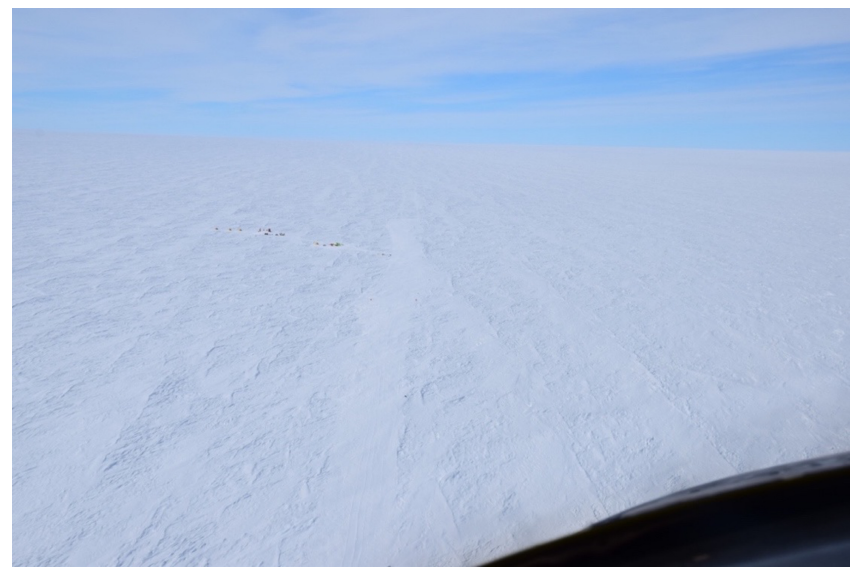

Figure A2. Sastrugi (as high as $0.5 \mathrm{~m}$ ) running in the west-east direction of approximately $80^{\circ}$ at Mount Brown South in East Antarctica during austral summer $2017 / 2018$ can be seen, particularly to the right of the image (a groomed ski-way for aircraft at a slightly deeper angle of approximately $110^{\circ}$ can be seen in the centre of the image). This indicates that the prevailing winds during the summer 2017/2018 season were east-north-easterlies. Photo credit: Doug Westersund/Kenn Borek Air.

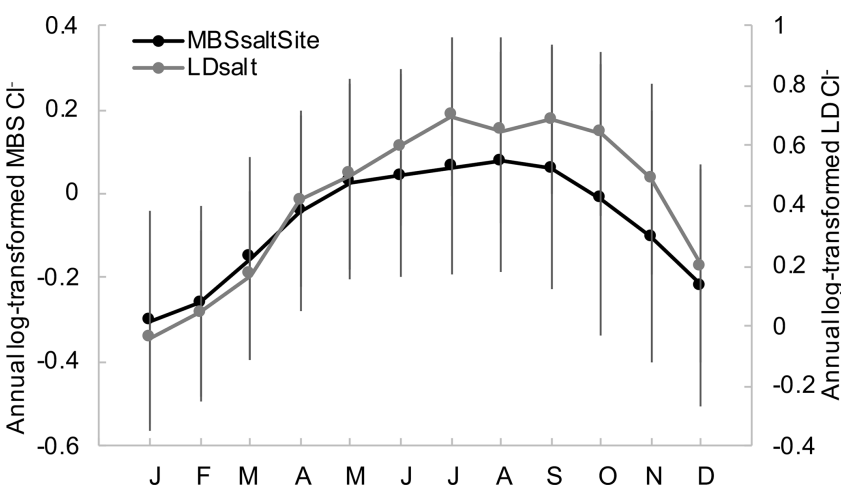

Figure A3. Climatology of the annual log-transformed sea salt concentrations for the Mount Brown South site average (MBSsaltSite) and Law Dome (Dome Summit South site; LDsalt) over the period 1975-2015/2016. Error bar vertical line plots give the $1 \sigma$ range of the composite monthly means.

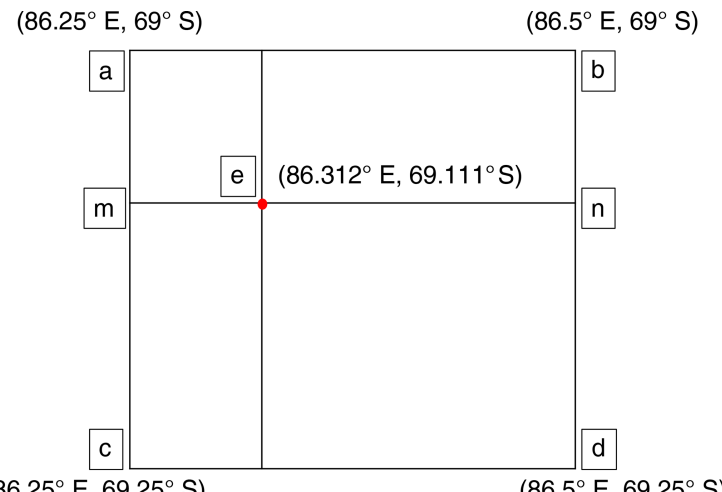

Figure A4. The location of the MBS Main ice core site (e) and the four nearby ERA5 pixels $(\mathbf{a}, \mathbf{b}, \mathbf{c}, \mathbf{d})$. The weighted average of the (a) and (c), shown by (m), and that of (b) and (d), shown by (n), were used to calculate the weighted average for the MBS Main site. 
Table A1. Pearson's correlation coefficient for the detrended annual log-transformed sea salt concentrations (sodium) for the Mount Brown South site average (MBSsaltSite) against detrended seasonal ENSO, SAM, and IOD indices. Correlations significant at $95 \%$ are shown in bold, and the dates range between 1975-2016. Where sodium concentrations were below detectable levels for ion chromatography, chloride concentrations were used with adjusted sea water ratios (six samples in the LD sodium record were below detectable levels).

\begin{tabular}{lllrrr}
\hline & Seasonal indices & Range & $r$ value & $p$ value \\
\hline MBSsaltSite & ENSO (Multivariate ENSO Index) & JJASON & $\mathbf{1 9 7 9 - 2 0 1 6}$ & $\mathbf{0 . 5 0 3}$ & $\mathbf{0 . 0 0 1}$ \\
& ENSO (4 Index) & JJASON & $\mathbf{1 9 7 5 - 2 0 1 6}$ & $\mathbf{0 . 4 8 6}$ & $\mathbf{0 . 0 0 1}$ \\
& ENSO (3.4 Index) & JJASON & $\mathbf{1 9 7 5 - 2 0 1 6}$ & $\mathbf{0 . 4 0 8}$ & $\mathbf{0 . 0 0 7}$ \\
ENSO (Southern Oscillation Index) & JJASON & $\mathbf{1 9 7 5 - 2 0 1 6}$ & $\mathbf{- 0 . 4 5 4}$ & $\mathbf{0 . 0 0 2}$ \\
& SAM (Marshall Index) & DJF (January year) & $1975-2016$ & 0.147 & 0.354 \\
SAM (Marshall Index) & MAM & $1975-2016$ & 0.304 & 0.050 \\
SAM (Marshall Index) & JJA & $1975-2016$ & 0.199 & 0.206 \\
SAM (Marshall Index) & SON & $1975-2016$ & -0.139 & 0.378 \\
SAM (Marshall Index) & DJF (December year) & $1975-2016$ & -0.384 & 0.068 \\
IOD (Dipole Mode Index) & SON & $1975-2016$ & 0.196 & 0.213 \\
\hline
\end{tabular}


Data availability. Data have been uploaded to the Australian Antarctic Data Centre at https://doi.org/10.4225/15/58eedf6812621 (Crockart et al., 2021).

Author contributions. CKC led the study, undertaking the majority of the data analysis and writing of the manuscript. TRV and ADF conceived the concept and design of the study and contributed substantially (along with ARK) to writing the manuscript. TRV, NJA, MAJC, CKC, ASC, VF, AJEG, HAK, ADM, CTP, LMJ, PTV, JW, and LZ contributed to the Mount Brown South ice core drilling project, ice core analysis and dating, calculation of snow accumulation rates, and ice core site climatology. ARK and LMJ assisted in the plotting and interpretation of the near-surface wind vectors, SST, geopotential height, and zonal wind composite anomaly maps. CK contributed the MAR simulations for the MBS region. All authors contributed to writing the manuscript and declare that they have no conflict of interest.

Competing interests. The authors declare that they have no conflict of interest.

Disclaimer. Publisher's note: Copernicus Publications remains neutral with regard to jurisdictional claims in published maps and institutional affiliations.

Acknowledgements. We thank Jason Roberts for assistance with this study and Sharon Labudda and the field team for retrieval of the Mount Brown South ice cores used in this study. Camilla K. Crockart is supported by an Australian Research Training scholarship and with Nerilie J. Abram is also supported by the Australian Research Council (ARC) Centre of Excellence for Climate Extremes. Tessa R. Vance acknowledges support from an ARC Discovery Project (DP180102522), and Tessa R. Vance and Alexander D. Fraser are supported by the ARC Special Research Initiative for Antarctic Gateway Partnership (SR140300001) and the Australian Antarctic Program Partnership (ASCI000002). This work contributes to Australian Antarctic Science projects (4414, 4537, and 4061), a Carlsberg Foundation grant to Paul T. Vallelonga, and a National Science Foundation project (NSF P2C2 18041212).

Financial support. This research has been supported by the Australian Research Council (ARC) Centre of Excellence for Climate Extremes, the ARC Discovery Project (grant no. DP180102522), the ARC Special Research Initiative for Antarctic Gateway Partnership (grant no. SR140300001), the Australian Antarctic Program Partnership (grant no. ASCI000002), Australian Antarctic Science projects 4414, 4537 and 4061, the Carlsberg Foundation, and the National Science Foundation (grant no. P2C2 18041212).

Review statement. This paper was edited by Mary Gagen and reviewed by two anonymous referees.

\section{References}

Abram, N. J., Mulvaney, R., Vimeux, F., Phipps, S. J., Turner, J., and England, M. H.: Evolution of the Southern Annular Mode during the past millennium, Nat. Clim. Chang., 4, 564-569, https://doi.org/10.1038/nclimate2235, 2014.

Abram, N. J., Wright, N. M., Ellis, B., Dixon, B. C., Wurtzel, J. B., England, M. H., Ummenhofer, C. C., Philibosian, B., Cahyarini, S. Y., Yu, T.-L., Shen, C.-C., Cheng, H., Edwards, R. L., and Heslop, D.: Coupling of Indo-Pacific climate variability over the last millennium, Nature, 579, 385-392, https://doi.org/10.1029/2019GL083906, 2020.

Agosta, C., Amory, C., Kittel, C., Orsi, A., Favier, V., Gallée, H., van den Broeke, M. R., Lenaerts, J. T. M., van Wessem, J. M., van de Berg, W. J., and Fettweis, X.: Estimation of the Antarctic surface mass balance using the regional climate model MAR (19792015) and identification of dominant processes, The Cryosphere, 13, 281-296, https://doi.org/10.5194/tc-13-281-2019, 2019.

Benassai, S., Becagli, S., Gragnani, R., Magand, O., Proposito, M., Fattori, I., Traversi, R., and Udisti, R.: Seaspray deposition in Antarctic coastal and plateau areas from ITASE traverses, Ann. Glaciol., 41, 30-41, https://doi.org/10.3189/172756405781813285, 2005.

Bigler, M., Svensson, A., Kettner, E., Vallelonga, P., Nielsen, M., and Steffensen, J.: Optimization of High-Resolution Continuous Flow Analysis for Transient Climate Signals in Ice Cores, Environ. Sci. Technol., 45, 4483-4489, 10.1021/es200118j, 2011.

Braganza, K., Gergis, J. L., Power, S. B., Risbey, J. S., and Fowler A. M.: A multiproxy index of the El Niño-Southern Oscillation, A.D. 1525-1982, J. Geophys. Res., 114, D05106, https://doi.org/10.1029/2008JD010896, 2009.

Bretherton, C. S., Widmann, M., Dymnikov, V. P., Wallace, J. M., and Blade I.: The effective number of spatial degrees of freedom of a time-varying field, J. Climate, 12, 1990-2009, https://doi.org/10.1175/15200442(1999)012<1990:TENOSD>2.0.CO;2, 1999.

Cai, W., Sullivan, A., and Cowan, T.: Interactions of ENSO, the IOD, and the SAM in CMIP3 Models, J. Climate, 24, 16881704, https://doi.org/10.1175/2010JCLI3744.1, 2011.

Cai, W., Zheng, X., Weller, E., Collins, M., Cowan, T., Lengaigne, M., Yu, W., and Yamagata, T.: Projected response of the Indian Ocean Dipole to greenhouse warming, Nat. Geosci., 6, 9991007, https://doi.org/10.1038/ngeo2009, 2013.

Carré, M., Sachs J. P., Purca, S., Schauer, A. J., Braconnot, P., Falcón, R. A., Julien, M., and Lavallée, D.: Holocene history of ENSO variance and asymmetry in the eastern tropical Pacific, Science, 345, 1045-1048, https://doi.org/10.1126/science.1252220, 2014.

Clem, K. R. and Fogt, R. L.: Varying roles of ENSO and SAM on the Antarctic Peninsula climate in austral spring, J. Geophys. Res.-Atmos., 118, 11481-11492, https://doi.org/10.1002/jgrd.50860, 2013.

Cobb, K. M., Charles, C. D., Cheng, H., and Edwards L.: El Niño/Southern Oscillation and tropical Pacific climate during the last millennium, Nature, 424, 271-276, https://doi.org/10.1038/nature01779, 2003.

Cobb, K. M., Westphal, N., Sayani, H. R., Watson, J. T., Di Lorenzo, E., Cheng, H., Edwards, R. L., and Charles, C. D.: Highly variable El Nino/Southern Oscillation throughout the Holocene, 
Science, 339, 67-70, https://doi.org/10.1126/science.1228246, 2013.

Crockart, C. K., Vance, T. R., Fraser, A. D., Abram, N. J., Criscitiello, A. S., Curran, M. A. J., Favier, V., Gallant, A. J. E., Kittel, C., Kjær, H. A., Klekociuk, A. R., Jong, L. M., Moy, A. D., Plummer, C. T., Vallelonga, P. T., Wille, J., and Zhang, L.: AAS_4414_MountBrownSouth_LawDome_icecores_seasalt_ accumulation_2020, Australian Antarctic Data Centre [data set], https://doi.org/10.4225/15/58eedf6812621, 2021.

Crueger, T., Zinke, J., and Pfeiffer, M.: Patterns of Pacific decadal variability recorded by Indian Ocean corals, Int. J. Earth Sci., 98, 41-52, https://doi.org/10.1007/s00531-008-0324-1, 2009.

Curran, M. A. J. and Palmer, A. S.: Suppressed ion chromatography methods for the routine determination of ultra low level anions and cations in ice cores, J. Chromatogr., 919, 107-113, https://doi.org/10.1016/S0021-9673(01)00790-7, 2001.

Curran, M. A. J., van Ommen, T. D., Morgan, V. I., Phillips, K. L., and Palmer, A. S.: Ice core evidence for Antarctic sea ice decline since the 1950s, Science, 302, 1203-1206, https://doi.org/10.1126/science.1087888, 2003.

Dätwyler, C., Neukom, R., Abram, N., Gallant, A., Grosjean, M., Jacques-Coper, M., Karoly, D., and Villalba, R.: Teleconnection stationarity, variability and trends of the Southern Annular Mode (SAM) during the last millennium, Clim. Dynam., 51, 23212339, https://doi.org/10.1007/s00382-017-4015-0, 2017.

Dätwyler, C., Abram, N. J., Grosjean, M., Wahl, E. R., and Neukom, R.: El Niño - Southern Oscillation variability, teleconnection changes and responses to large volcanic eruptions since $\mathrm{AD}$ 1000, Int. J. Climatol., 39, 2711-2724, https://doi.org/10.1002/joc.5983, 2019.

Dätwyler, C., Grosjean, M., Steiger, N. J., and Neukom, R.: Teleconnections and relationship between the El Niño-Southern Oscillation (ENSO) and the Southern Annular Mode (SAM) in reconstructions and models over the past millennium, Clim. Past, 16, 743-756, https://doi.org/10.5194/cp-16-743-2020, 2020.

Ding, Q., Steig, E. J., Battisti, D. S., and Küttel, M.: Winter warming in West Antarctica caused by central tropical Pacific warming, Nat. Geosci., 4, 398-403, https://doi.org/10.1038/ngeo1129, 2011.

Ding, Q., Steig, E. J., Battisti, D. S., and Wallace J. M.: Influence of the tropics on the Southern Annular Mode, J. Climate, 25, 63306348, https://doi.org/10.1175/JCLI-D-11-00523.1, 2012.

Donat-Magnin, M., Jourdain, N. C., Gallée, H., Amory, C., Kittel, C., Fettweis, X., Wille, J. D., Favier, V., Drira, A., and Agosta, C.: Interannual variability of summer surface mass balance and surface melting in the Amundsen sector, West Antarctica, The Cryosphere, 14, 229-249, https://doi.org/10.5194/tc14-229-2020, 2020.

Emile-Geay, J., Cobb, K., Carré, M., Braconnot, P., Leloup, J., Zhou, Y., Harrison, S. P., Corrège, T., Mcgregor, H., Collins, M., Driscoll, R., Elliot, M., Schneider, B., and Tudhope, A. W.: Links between tropical Pacific seasonal, interannual and orbital variability during the Holocene, Nat. Geosci., 9, 168-173, https://doi.org/10.1038/ngeo2608, 2015.

Fischer, A., Terray, P., Guilyardi, E., Gualdi, S., and Delecluse, P: Two Independent Triggers for the Indian Ocean Dipole/Zonal Mode in a Coupled GCM, J. Climate, 18, 3428-3449, https://doi.org/10.1175/JCLI3478.1, 2005.
Fogt R. L. and Bromwich, D. H.: Decadal variability of the ENSO teleconnection to the high latitude South Pacific governed by coupling with the Southern Annular Mode, J. Climate, 19, 979997, https://doi.org/10.1175/JCLI3671.1, 2006.

Fogt, R. L. Bromwich, D. H., and Hines, K. M.: Understanding the SAM influence on the South Pacific ENSO teleconnection, Clim. Dynam., 36, 1555-1576, https://doi.org/10.1007/s00382011-1201-3, 2011.

Fogt, R. L., Jones, J. M., and Renwick, J.: Seasonal Zonal Asymmetries in the Southern Annular Mode and Their Impact on Regional Temperature Anomalies, J. Climate, 25, 6253-6270, https://doi.org/10.1175/JCLI-D-11-00474.1, 2012.

Foster, A., Curran, M., Smith, B. T., van Ommen, T., and Morgan, V.: Covariation of sea ice and methanesulphonic acid in Wilhelm II Land, East Antarctica, Ann. Glaciol., 44, 429-432, https://doi.org/10.3189/172756406781811394, 2006.

Fowler, A. M., Boswijk, G., Lorrey, A. M., Gergis, J., Pirie, M., McCloskey, S. P. J., Palmer, J. G., and Wunder, J.: Multi-centennial tree-ring record of ENSO-related activity in New Zealand, Nat. Clim. Chang., 2, 172-176, https://doi.org/10.1038/nclimate1374, 2012.

Freund, M. B., Henley, B. J., Karoly, D. J., McGregor, H. V., Abram, N. J., and Dommenget, D.: Higher frequency of Central Pacific El Niño events in recent decades relative to past centuries, Nat. Geosci., 12, 450-455, https://doi.org/10.1038/s41561-019-03533, 2019.

Gallée, H. and Schayes, G.: Development of a three-dimensional meso- $\gamma$ primitive equation model: katabatic winds simulation in the area of Terra Nova Bay, Antarctica, Mon. Weather Rev., 122, 671-685, 1994.

Gong, T., Feldstein, S. B., and Luo, D.: The impact of ENSO on wave breaking and southern annular mode events, J. Atmos. Sci., 67, 2854-2870, https://doi.org/10.1175/2010JAS3311.1, 2010.

Goodwin, I., van Ommen, T., Curran, M., and Mayewski, P.: Mid latitude winter climate variability in the South Indian and southwest Pacific regions since 1300 AD, Clim. Dynam., 22, 783-794, https://doi.org/10.1007/s00382-004-0403-3, 2004.

Gorodetskaya, I., Tsukernik, M., Claes, K., Ralph, F., Neff, W., and Lipzig, N.: The role of atmospheric rivers in anomalous snow accumulation in East Antarctica, Geophys. Res. Lett., 41, 61996206, https://doi.org/10.1002/2014GL060881, 2014.

Grazioli, J., Madeleine, J.-B., Gallée, H., Forbes, R. M., Genthon, C., Krinner, G., and Berne, A.: Katabatic winds diminish precipitation contribution to the Antarctic ice mass balance, P. Natl. Acad. Sci. USA, 114, 10858-10863, https://doi.org/10.1073/pnas.1707633114, 2017.

Grothe, P. R., Cobb, K. M., Liguori, G., Di Lorenzo, E., Capotondi, A., Lu, Y., Cheng, H., Edwards, R. L., Southon, J. R., Santos, G. M., Deocampo, D. M., Lynch-Stieglitz, J., Chen, T., Sayani, H. R., Thompson, D. M., Conroy, J. L., Moore, A. L., Townsend, K., Hagos, M., O'Connor, G., and Toth, L. T.: Enhanced El Niño-Southern Oscillation variability in recent decades, Geophys. Res. Lett., 47, e2019GL083906, https://doi.org/10.1029/2019GL083906, 2019.

Guo, F., Liu, Q., Sun, S., and Yang, J.: Three Types of Indian Ocean Dipoles, J. Climate, 28, 3073-3092, https://doi.org/10.1175/JCLI-D-14-00507.1, 2015.

Hessl, A., Allen K. J., Vance, T., Abram, N. J., and Saunders, K. M.: Reconstructions of the southern annular mode (SAM) 
during the last millennium, Prog. Phys. Geog., 14, 834-849, https://doi.org/10.1177/0309133317743165, 2017.

Hosking, J. S., Orr, A., Marshall, G. J., Turner, J., and Phillips, T.: The Influence of the Amundsen-Bellingshausen Seas Low on the Climate of West Antarctica and Its Representation in Coupled Climate Model Simulations, J. Climate, 26, 6633-6648, https://doi.org/10.1175/JCLI-D-12-00813.1, 2013.

IPCC: Climate Change 2013: The Physical Science Basis. Contribution of Working Group I to the Fifth Assessment Report of the Intergovernmental Panel on Climate Change, edited by: Stocker, T. F., Qin, D., Plattner, G.-K., Tignor, M., Allen, S. K., Boschung, J., Nauels, A., Xia, Y., Bex, V., and Midgley, P. M., Cambridge University Press, Cambridge, UK and New York, NY, USA, 1535 pp., 2013.

Johnsen, S., Hansen, S., Sheldon, S., Dahl-Jensen, D., Steffensen, J., Augustin, L., Journé, P., Alemany, O., Rufli, H., Schwander, J., Azuma, N., Motoyama, H., Popp, T., Talalay, P., Thorsteinsson, T., Wilhelms, F., and Zagorodnov, V.: The Hans Tausen drill: Design, performance, further developments and some lessons learned, Ann. Glaciol., 47, 89-98, https://doi.org/10.3189/172756407786857686, 2007.

Kim, B., Choi, H., Kim, S., Kim, S.-J., and Choi, W.: Amplitudedependent relationship between the Southern Annular Mode and the El Niño Southern Oscillation in austral summer, Asia-Pacific, J. Atmos. Sci., 53, 85-100, https://doi.org/10.1007/s13143-0170007-6, 2017.

Kittel, C., Amory, C., Agosta, C., Jourdain, N. C., Hofer, S., Delhasse, A., Doutreloup, S., Huot, P.-V., Lang, C., Fichefet, T., and Fettweis, X.: Diverging future surface mass balance between the Antarctic ice shelves and grounded ice sheet, The Cryosphere, 15, 1215-1236, https://doi.org/10.5194/tc-15-1215-2021, 2021.

Legrand, M. and Mayewski, P.: Glaciochemistry of polar ice cores: A review, Rev. Geophys., 35, 219-243, https://doi.org/10.1029/96RG03527, 1997.

L'Heureux, M. L. and Thompson, D. W.: Observed Relationships between the El Niño-Southern Oscillation and the Extratropical Zonal-Mean Circulation, J. Climate, 19, 276-287, https://doi.org/10.1175/JCLI3617.1, 2006.

Li, L. and Pomeroy, J.: Estimates of Threshold Wind Speeds for Snow Transport Using Meteorological Data, J Appl. Meterol., 36, 205-213, https://doi.org/10.1175/15200450(1997)036<0205:EOTWSF>2.0.CO;2, 1997.

Lim, E.-P., Hendon, H., and Rashid, H.: Seasonal Predictability of the Southern Annular Mode due to Its Association with ENSO, J. Climate, 26, 8037-8054, https://doi.org/10.1175/JCLI-D-13$00006.1,2013$.

Markgraf, V. and Diaz H. F. The Past ENSO Record: A Synthesis, in: El Niño and the Southern Oscillation: Multiscale Variability and Global and Regional Impacts, edited by: Diaz, H. F. and Markgraf, V., Cambridge University Press, Cambridge, UK, 463-486, 2000.

Marshall, G. J.: Trends in the southern annular mode from observations and reanalyses, J. Climate, $16, \quad 4134-4143$, https://doi.org/10.1175/15200442(2003)016<4134:TITSAM>2.0.CO;2, 2003.

Marshall, J., Scott, J. R., Romanou, A., Kelley, M., and Leboissetier, A.: The dependence of the ocean's MOC on mesoscale eddy diffusivities: A model study, Ocean Model., 111, 1-8, https://doi.org/10.1016/j.ocemod.2017.01.001, 2017.
Massom, R., Pook, M., Comiso, J., Adams, N., Turner, J., LachlanCope, T., and Gibson, T.: Precipitation over the Interior East Antarctic Ice Sheet Related to Midlatitude Blocking-High Activity, J. Climate, 17, 1914-1928, https://doi.org/10.1175/15200442(2004)017<1914:POTIEA>2.0.CO;2, 2004.

McIntosh, P. and Hendon, H:. Understanding Rossby wave trains forced by the Indian Ocean Dipole, Clim. Dynam., 50, 2783 2798, https://doi.org/10.1007/s00382-017-3771-1, 2018.

McMorrow, A. J., Curran, M. A. J., van Ommen, T.D., Morgan, V., Pook, M. J., and Allison, I.: Intercomparison of firn core and meteorological data, Antarct. Sci., 13, 329-337, https://doi.org/10.1017/S0954102001000463, 2001.

McPhaden, M. J., Zebiak, S. E., and Glantz, M. H.: ENSO as an integrating concept in earth science, Science, 314, 1740-1745, https://doi.org/10.1126/science.1132588, 2006.

Medley, B. and Thomas E. R.: Increased snowfall over the Antarctic Ice Sheet mitigated twentieth-century sea-level rise, Nat. Clim. Chang., 9, 34-39, https://doi.org/10.1038/s41558-018-0356-x, 2018.

Morgan, V., Wookey, C., Li, J., van Ommen, T., Skinner, W., and Fitzpatrick, M.: Site information and initial results from deep ice drilling on Law Dome, Antarctica, J. Glaciol., 43, 3-10, https://doi.org/10.3189/S0022143000002768, 1997.

Newman, M., Alexander, M. A., Ault, T. R., Cobb, K., Deser, K., Di Lorenzo, E., Mantua, N. J., Miller, A. J., Minobe, S., Nakamura, H., Schneider, N., Vimont, D. J., Phillips, A. S., Scott, J. D., and Smith C. A.: The Pacific Decadal Oscillation, Revisited, J. Climate, 29, 4399-4427, https://doi.org/10.1175/JCLI-D-150508.1, 2016.

Nuncio, M. and Yuan, X.: The Influence of the Indian Ocean Dipole on Antarctic Sea Ice, J. Climate, 28, 2682-2690, https://doi.org/10.1175/JCLI-D-14-00390.1, 2015.

PAGES 2k Consortium: Continental-scale temperature variability during the past two millennia, Nat. Geosci., 6, 339-346, https://doi.org/10.1038/ngeo1834, 2013.

Palmer, A. S., van Ommen T. D., Curran, M. A. J., Morgan, V., Souney, J. M., and Mayewski, P. A.: High precision dating of volcanic events (AD 1301-1995) using ice cores from Law Dome, Antarctica, J. Geophys. Res., 106, 28089-28095, https://doi.org/10.1029/2001JD000330, 2001.

Parker, D.: Documentation of a Southern Oscillation Index, Meteor. Mag., 12, 184-188, 1983.

Plummer, C. T., Curran, M. A. J., van Ommen, T. D., Rasmussen, S. O., Moy, A. D., Vance, T. R., Clausen, H. B., Vinther, B. M., and Mayewski, P. A.: An independently dated 2000-yr volcanic record from Law Dome, East Antarctica, including a new perspective on the dating of the 1450s CE eruption of Kuwae, Vanuatu, Clim. Past, 8, 1929-1940, https://doi.org/10.5194/cp8-1929-2012, 2012.

Pook, M. and Gibson, T.: Atmospheric blocking and storm tracks during SOP-1 of the FROST Project, Aust. Meteorol. Mag., 48, 51-60, 1999.

Power, S., Casey, T., Folland, C., Colman, A., and Mehta, V.: Interdecadal modulation of the impact of ENSO on Australia, Clim. Dynam., 15, 319-324, https://doi.org/10.1007/s003820050284, 1999.

Purich, A. and England, M. H.: Tropical teleconnections to Antarctic sea ice during austral spring 2016 in coupled 
pacemaker experiments, Geophys. Res. Lett., 46, 6848-6858, https://doi.org/10.1029/2019GL082671, 2019.

Roberts, J., Plummer, C., Vance, T., van Ommen, T., Moy, A., Poynter, S., Treverrow, A., Curran, M., and George, S.: A 2000-year annual record of snow accumulation rates for Law Dome, East Antarctica, Clim. Past, 11, 697-707, https://doi.org/10.5194/cp11-697-2015, 2015.

Saji, N. H., Goswami, B. N., Vinayachandran, P. N., and Yamagata, T.: A dipole mode in the tropical Indian Ocean, Nature, 401, 360363, https://doi.org/10.1038/43854, 1999.

Scarchilli, C., Frezzotti, M., and Ruti, P.: Snow precipitation at four ice core sites in East Antarctica: Provenance, seasonality and blocking factors, Clim. Dynam., 37, 2107-2125, https://doi.org/10.1007/S00382-010-0946-4, 2011.

Scott, R. C., Nicolas, J. P., Bromwich, D. H., Norris, J. R., and Lubin D.: Meteorological Drivers and Large-Scale Climate Forcing of West Antarctic Surface Melt, J. Climate, 32, 665-684, https://doi.org/10.1175/JCLI-D-18-0233.1, 2019.

Sheldon, S. G., Popp T. J., Hansen, S. B., Hedegaard, T. M., and Mortensen, C.: A new intermediate-depth ice-core drilling system, Ann. Glaciol., 55, 271-284, https://doi.org/10.3189/2014AoG68A038, 2014.

Smith, B., van Ommen, T., and Morgan, V.: Distribution of oxygen isotope ratios and snow accumulation rates in Wilhelm II Land, East Antarctica, Ann. Glaciol., 35, 107-110, https://doi.org/10.3189/172756402781816898, 2002.

Stahle, D., D’Arrigo, R., Krusic, P., Cleaveland, M., Cook, E., Allan, R., Cole, J., Dunbar, R., Therrell, M., and Gay, D.: Experimental Dendroclimatic Reconstruction of the Southern Oscillation, Bull. Am. Meteorol. Soc., 79, 2137-2151, https://doi.org/10.1175/15200477(1998)079<2137:EDROTS>2.0.CO;2, 1998.

Stenni, B., Curran, M. A. J., Abram, N. J., Orsi, A., Goursaud, S., Masson-Delmotte, V., Neukom, R., Goosse, H., Divine, D., van Ommen, T., Steig, E. J., Dixon, D. A., Thomas, E. R., Bertler, N. A. N., Isaksson, E., Ekaykin, A., Werner, M., and Frezzotti, M.: Antarctic climate variability on regional and continental scales over the last 2000 years, Clim. Past, 13, 1609-1634, https://doi.org/10.5194/cp-13-1609-2017, 2017.

Tetzner, D., Thomas, E., and Allen, C.: A Validation of ERA5 Reanalysis Data in the Southern Antarctic Peninsula - Ellsworth Land Region, and Its Implications for Ice Core Studies, Geosci. J., 9, 289, https://doi.org/10.3390/geosciences9070289, 2019.

Thomas, E. R., van Wessem, J. M., Roberts, J., Isaksson, E., Schlosser, E., Fudge, T. J., Vallelonga, P., Medley, B., Lenaerts, J., Bertler, N., van den Broeke, M. R., Dixon, D. A., Frezzotti, M., Stenni, B., Curran, M., and Ekaykin, A. A.: Regional Antarctic snow accumulation over the past 1000 years, Clim. Past, 13, 1491-1513, https://doi.org/10.5194/cp-13-1491-2017, 2017.

Thompson, D. W., Wallace, J. M., and Hegerl, G. C.: Annular Modes in the Extratropical Circulation. Part II: Trends, J. Climate, 13, 1018-1036, https://doi.org/10.1175/15200442(2000)013<1018:AMITEC>2.0.CO;2, 2000.

Trenberth, K. E.: The Definition of El Niño, Bull. Amer. Meteor. Soc., 78, 2771-2777, https://doi.org/10.1175/15200477(1997)078<2771:TDOENO>2.0.CO;2, 1997.

Turner, J.: The El Niño-Southern Oscillation and Antarctica, Int. J. Climatol., 24, 1-31, https://doi.org/10.1002/joc.965, 2004.
Turner, J., Orr, A., Gudmundsson, G. H., Jenkins, A., Bingham, R. G., Hillenbrand, C.-D., and Bracegirdle, T. J.: Atmosphere-ocean-ice interactions in the Amundsen Sea Embayment, West Antarctica, Rev. Geophys., 55, 235-276, https://doi.org/10.1002/2016RG000532, 2017.

Turner, J., Phillips, T., Thamban, M., Rahaman, W., and Marshall, G. J.: The Dominant Role of Extreme Precipitation Events in Antarctic Snowfall Variability, Geophys. Res. lett., 46, 35023511, https://doi.org/10.1029/2018GL081517, 2019.

Udy, D. G., Vance, T. R., Kiem, A. S., Holbrook, N. J., and Curran, M. A. J.: Links between large-scale modes of climate variability and synoptic weather patterns in the southern Indian Ocean, J. Climate, 34, 883-899, https://doi.org/10.1175/JCLI-D20-0297.1, 2021.

Vance, T. R., van Ommen, T. D., Curran, M. A. J., Plummer, C. T., and Moy, A. D.: A Millennial Proxy Record of ENSO and Eastern Australian Rainfall from the Law Dome Ice Core, East Antarctica, J. Climate, 26, 710-725, https://doi.org/10.1175/JCLI-D-12-00003.1, 2013.

Vance, T., Roberts, J., Plummer, C., Kiem, A., and van Ommen, T.: Interdecadal Pacific variability and Australian mega-droughts over the last millennium, Geophys. Res. Lett., 42, 129-137, https://doi.org/10.1002/2014GL062447, 2015.

Vance, T. R., Roberts, J. L., Moy, A. D., Curran, M. A. J., Tozer, C. R., Gallant, A. J. E., Abram, N. J., van Ommen, T. D., Young, D. A., Grima, C., Blankenship, D. D., and Siegert, M. J.: Optimal site selection for a high-resolution ice core record in East Antarctica, Clim. Past, 12, 595-610, https://doi.org/10.5194/cp12-595-2016, 2016.

van Ommen, T. D. and Morgan, V.: Peroxide concentrations in the Dome Summit South ice core, Law Dome, Antarctica, J. Geophys. Res., 101, 15147, https://doi.org/10.1029/96JD00838, 1996.

van Ommen, T. D. and Morgan, V.: Snowfall increase in coastal East Antarctica linked with southwest Western Australian drought, Nat. Geosci., 3, 267-272, https://doi.org/10.1038/ngeo761, 2010.

van Ommen, T. D., Morgan, V., and Curran, M. A. J.: Deglacial and Holocene changes in accumulation at Law Dome, East Antarctica, Ann. Glaciol., 39, 359-365, https://doi.org/10.3189/172756404781814221, 2004.

Villalba, R., Lara, A., Masiokas, M., Urrutia, R., Luckman, B., Marshall, G., Mundo, I., Christie, D., Cook, E., Neukom, R., Allen, K., Fenwick, P., Boninsegna, J., Morales, M., Araneo, D., Palmer, J., Cuq, E.. Srur, A., Aravena, J., and LeQuesne, C.: Unusual Southern Hemisphere tree growth patterns induced by changes in the Southern Annular Mode, Nat. Geosci. 5, 793-798, https://doi.org/10.1038/ngeo1613, 2012.

Webster, P. J., Moore, A. M., Loschnigg, J. P., and Leben, R. R.: Coupled ocean-atmosphere dynamics in the Indian Ocean during 1997-98, Nature, 401, 356-360, https://doi.org/10.1038/43848, 1999.

Westra, S., Renard, B., and Thyer, M.: The ENSOPrecipitation Teleconnection and Its Modulation by the Interdecadal Pacific Oscillation, J. Climate, 28, 4753-4773, https://doi.org/10.1175/JCLI-D-14-00722.1, 2015.

Wille, J. D., Favier, V., Dufour, A., Gorodetskaya, I. V., Turner, J., Agosta, C., and Codron, F.: West Antarctic surface melt 
triggered by atmospheric rivers, Nat. Geosci., 12, 911-916, https://doi.org/10.1038/s41561-019-0460-1, 2019.

Wille, J. D., Favier, V., Gorodetskaya, I. V., Agosta, C., Kittel C., Chowdhry Beeman, J., Jourdain N., Lenaerts, J. T. M., and Codron, F.: Antarctic atmospheric river climatology and precipitation impacts, J. Geophys. Res.-Atmos., 126, e2020JD033788, https://doi.org/10.1029/2020JD033788, 2021.

Wolter, K. and Timlin, M. S.: El Niño-Southern Oscillation behaviour since 1871 as diagnosed in an extended multivariate ENSO index (MEI.ext), Int. J. Climatol., 11, 1074-1087, https://doi.org/10.1002/joc.2336, 2011.

Yiu, Y. Y. S. and Maycock, A. C .: On the Seasonality of the El Niño Teleconnection to the Amundsen Sea Region, J. Climate, 32, 4829-4845, https://doi.org/10.1175/JCLI-D-18-0813.1, 2019.
Yu, J., Paek, H., Saltzman, E. S., Lee, T.: The Early 1990s Change in ENSO-PSA-SAM Relationships and Its Impact on Southern Hemisphere Climate, J. Climate, 28, 9393-9408, https://doi.org/10.1175/JCLI-D-15-0335.1, 2015.

Zhang, Z. Y., Gong, D., He, X. Z., Lei, Y.-N., and Feng, S.-H.: Statistical reconstruction of the Antarctic Oscillation Index based on multiple proxies, Atmospheric and Oceanic Science Letters, 3, 283-287, https://doi.org/10.1080/16742834.2010.11446883, 2010. 